\title{
Research Paper \\ The Mediating Role of Mindfulness in the Relationship between Self-Regulated Learning and Goal Orientation with Academic Identity
}

Farzane Yousefi $^{1}$, Zahra Zeinaddiny Meymand $^{* 2}$, Vidasadat Razavi Nematollahi ${ }^{2}$, Amanallah Soltani ${ }^{2}$

1. Ph.D. Student of Educational Psychology, Department of Psychology, Kerman Branch, Islamic Azad University, Kerman, Iran. 2. Assistant Professor, Department of Educational Sciences and Psychology, Kerman Branch, Islamic Azad University, Kerman, Iran

Citation: Yousefi F, Zeinaddiny Meymand Z, Razavi Nematollahi V, Soltani A. The mediating role of mindfulness in the relationship between self-regulated learning and goal orientation with academic identity. Quarterly Journal of Child Mental Health. 2019; 6(3): $228-241$.

http://dx.doi.org/10.29252/jemh.6.3.20

\section{A R T I C L E I N F O}

\section{Keywords:}

Educational identity, mindfulness, self-regulatory learning, goal orientation

Received: 11 Dec 2017 Accepted: 7 Aug 2018 Available: 16 Nov 2019

\section{A B S T R A C T}

Background and Purpose: Academic identity is the most important factor in student performance and motivation for student development that can influence classroom behavior; desire to go to school, and one's perception of themselves. If a person has a good idea of himself, he will try to be successful. Therefore, the present study aimed to investigate the mediating role of mindfulness in the relationship between self-regulated learning and goal orientation with educational identity.

Method: The design of the present study is the correlation with the structural modeling method. The statistical population of this study consisted of all high school students in Nehbandan city in the academic year of 2015-2016. 216 students were selected by multistage cluster sampling as a sample. For data collection, the academic identity questionnaire (Weas \& Isaacson, 2008); goal orientation (Midgley et al., 1998), self-regulated learning strategies (Pentrich \& De Groot, 1990) and mindfulness questionnaires (Bauer et al., 2010) were used. Exploratory factor analysis, confirmatory factor analysis, and structural equation modeling were used to investigate the research hypothesis. Data were analyzed using SPSS and LISREL software.

Results: The results showed that according to the presented indices, the mediating role of mindfulness in the relationship between self-regulated learning and goal orientation with academic identity is confirmed; In other words, self-regulated learning and goal orientation with mediating mindfulness have a positive and significant indirect effect on academic identity. Also, the direct effects of mindfulness, self-regulation learning, and goal orientation on academic identity were 0.50 , 0.68 and 0.12 , respectively; the direct effect of self-regulation learning and goal orientation on mindfulness, respectively, 0.54 and 0.12 , respectively; and the effect of total self-regulated learning and goal orientation on academic identity with mediating mindfulness was 0.95 and 0.18 , respectively.

Conclusion: Given the importance of goal orientation and academic motivation for long-term learning success and generalization, attention to metacognitive strategies, planning, review, and mental adjustment should be incorporated into curriculum so that the learning process is gradually adapted with learner characteristics and needs.

\footnotetext{
* Corresponding author: Zahra Zeinaddiny Meymand, Assistant Professor, Department of Educational Sciences and Psychology, Kerman Branch, Islamic Azad University, Kerman, Iran.

E-mail addresses: Zeinaddiny@gmail.com
} 


\section{نقش واسطهاى ذهن آكاهى در رابطه بين يادكيرى خودتنظيمى و جهت كيرى هدف با هويت تحصيلى

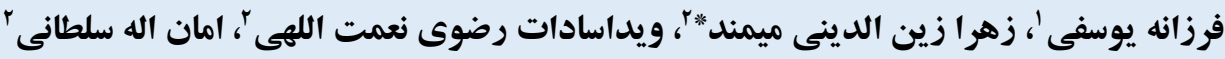 \\ ا. دانشجوى د كتر ایى روانشناسى تربيتى، واحد كرمان، دانشگاه آزاد اسلامى، كرمان، ايران ان

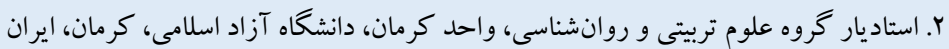

جكيده

زمينه و هدف: هويت تحصـيلى ههمترين عامل در عملكرد تحصـيلى و انخيزه ييشـرفت دانش آموزان اســت كه مىتواند بر رفتارهاى

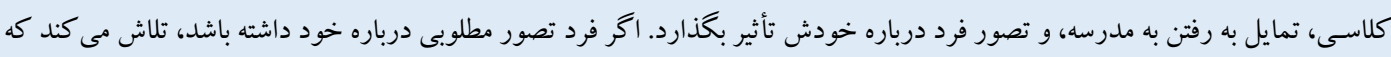

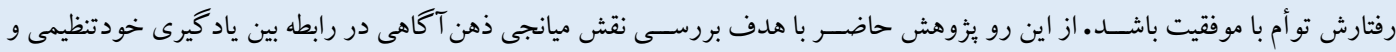
جهت گيرى هدف با هويت تحصيلى انجام شد.

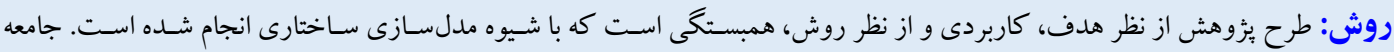

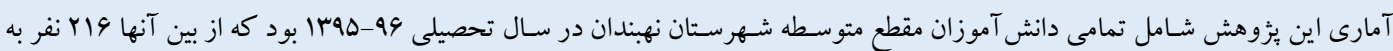

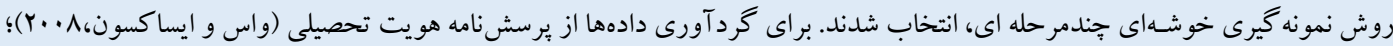

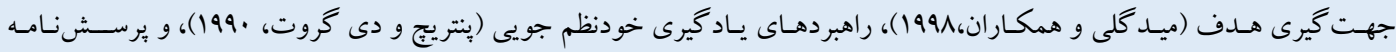

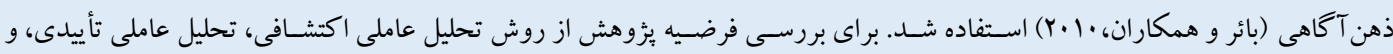

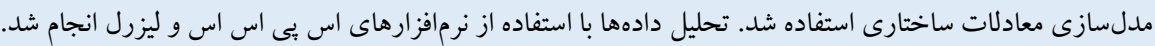
يافتها: نتايج يثزوهش نشـان داد كه با توجه به شـاخصهاى ارائه شـده، نقش واسـطهاى ذهن آكاهى در رابطه بين ياد گيرى خود تنظيمى و

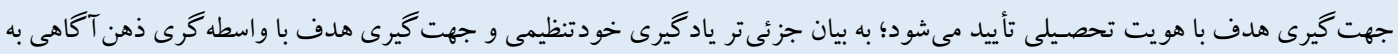

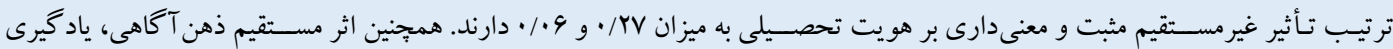

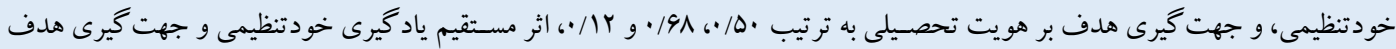

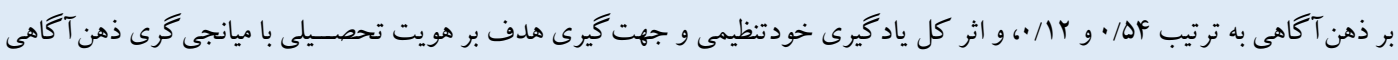

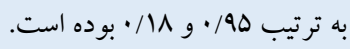
نتيجـهـ كيرى: بـا توجـه بـه اهميـت جهت كيرى هدف و انخيزش تحصـيلى براى موفق شـــن و بايدارى ياد گيرى در بلندمدت، توجه به

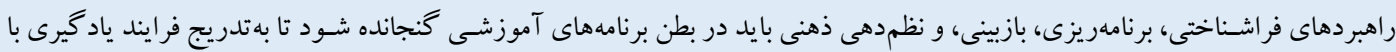
ويزگ گىهاى ياد گيرنده و نيازهاى شخصى و شخصيتى او، همسو شود.
مشخصات مقاله

كليدوازهها:

هويت تحصيلى،

ذهن آكاهى،

ياد گيرى خود تنظيمى،

جهت گيرى هدف

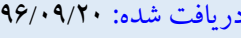

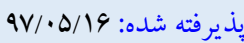
منتشر شده: S (

* نويسنده مسئول: زهرا زين الدينى ميمند، استاديار گروه علوم تربيتى و روانشناسى، واحد كرمان، دانشكاه آزاد اسلامى، كرمان، ايران.

Zeinaddiny@gmail.com : رايانامه

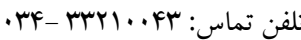


جديد از ويز گى هاى كليدى شكل گيرى هويت تحصسيلى موفق است و

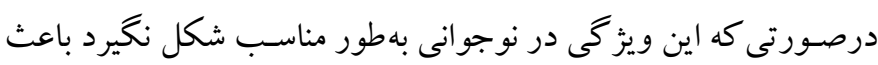

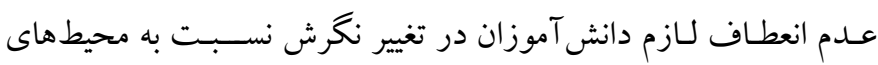
آموزشى خو اهد شد (ه).

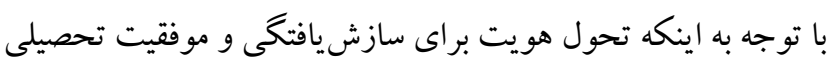
ضرورى اسـت تشكيل هويت تحصيلى بستكى به زمينه اجتماعى مدرسه

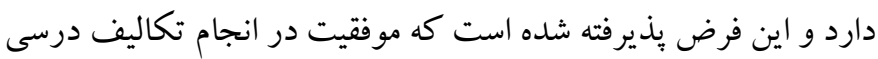

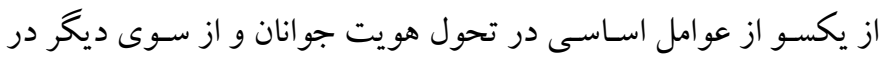

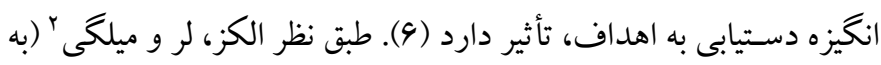

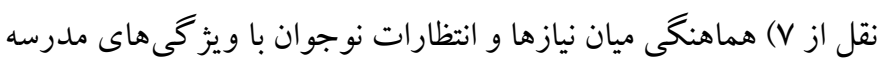

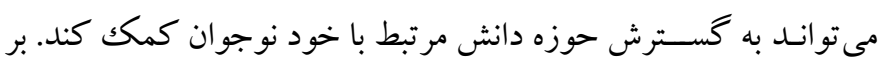

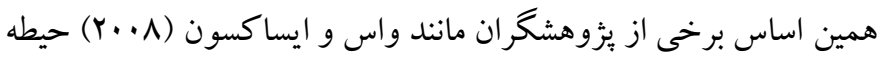

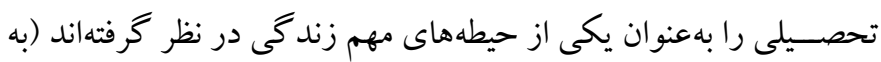

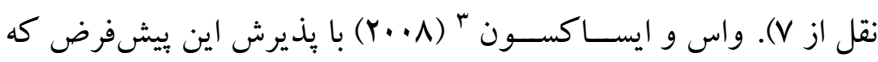

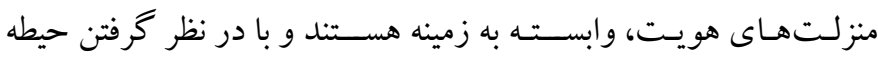

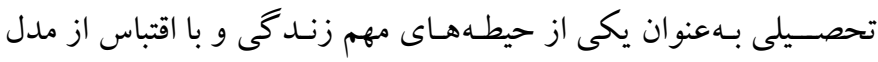

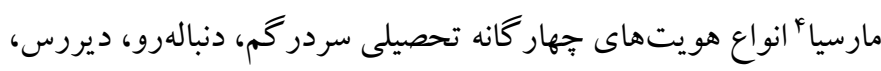

$$
\text { و موفق را ارائه كردند (به نقل از م). }
$$

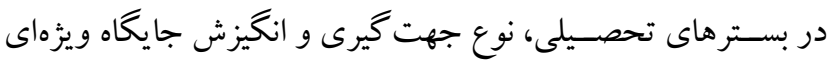

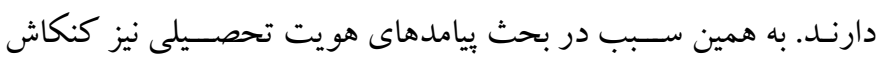

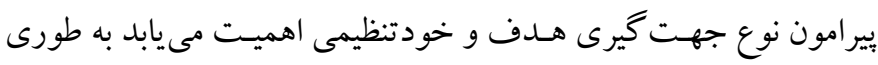

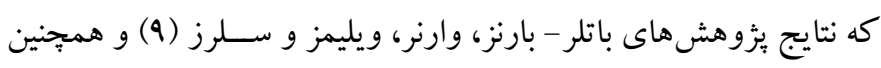

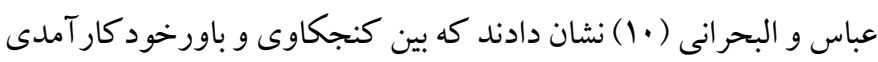

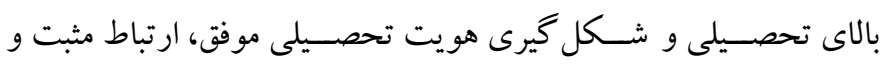

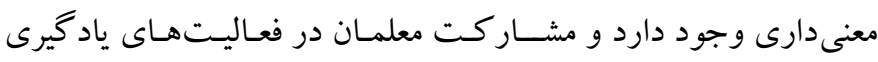

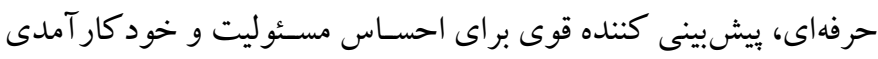

معلمان است (11).

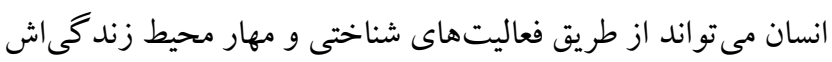

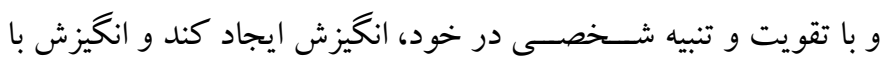

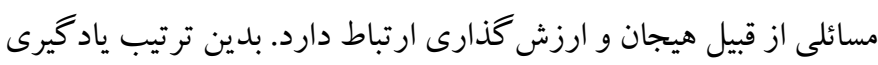

3. Was \& Isaacson 4. Marcia

\section{مقلدمه}

امروزه نقش عوامل روانشناختى و تأييد آن بر جنبههاى مختلف زندكى

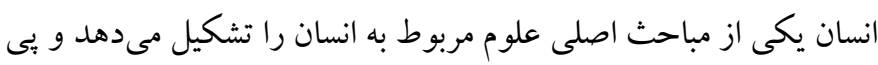

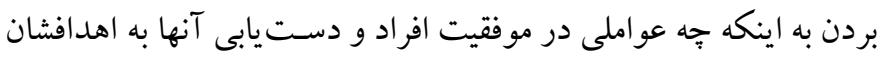

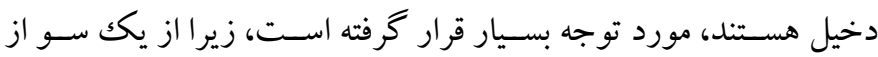

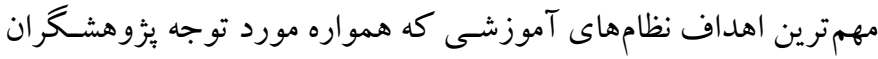

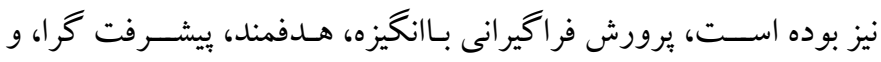

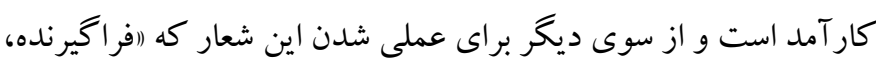

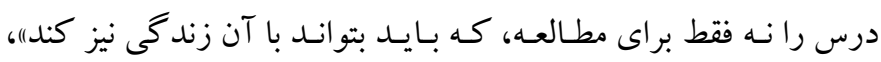

مىبايست هويت مناسب آن درس را كسب كند (1).

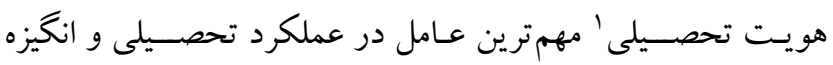

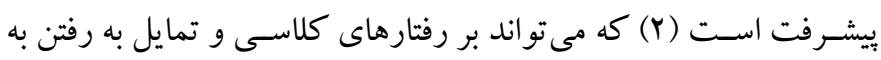

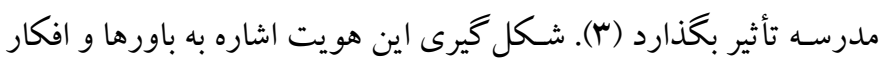

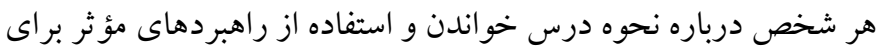
كسب موفقيت در اين مسير دارد كه در صسورت تحقق اين امر به ايجاد

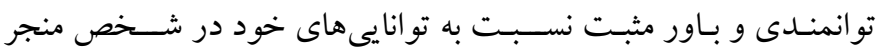

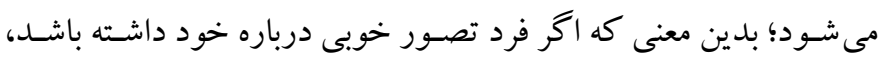

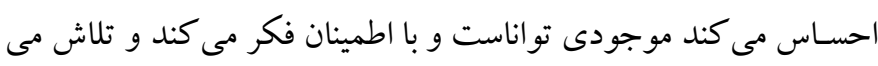

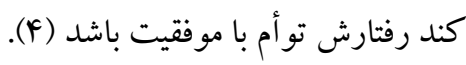
همجنين هويت تحصسيلى، مى تواند از عوامل فردى مؤثر بر بيشـرفت

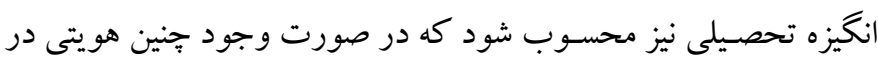
فرد، نوعى احساس براى حركت و موفقيت در جنبه هاى مختلف تحصيلى ميره

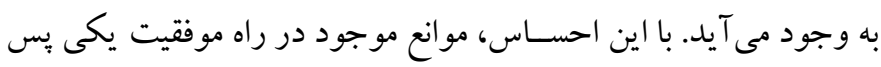

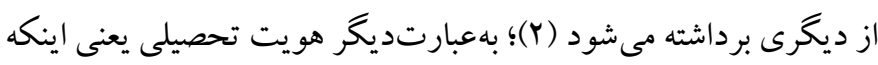
دانش آموزان باور داشـته باشـند كه براى داشـتن احسـاس مثبتى در مورد

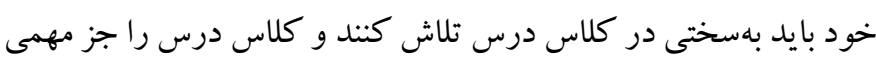

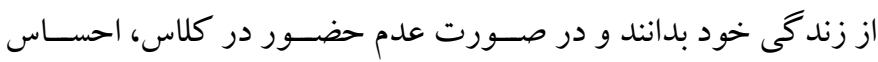

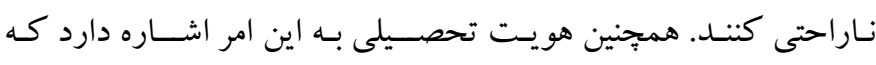

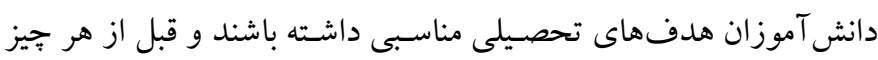

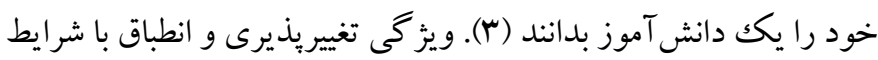

1. Educational Identity

2. Alkez, Loor \&Milgi 
لحظه، شـناخت، احسـاس و فرايندهاى انخيزشـى رادر روند يادكيرى

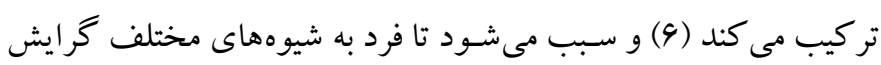

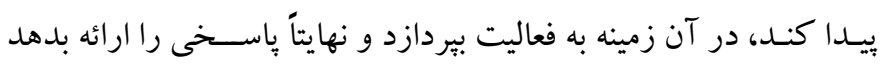

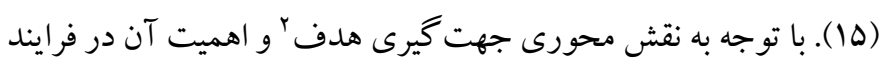

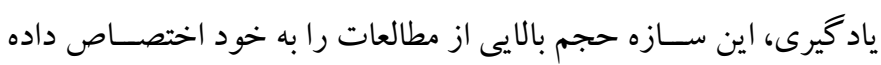

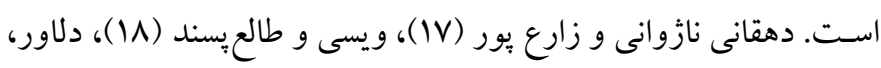

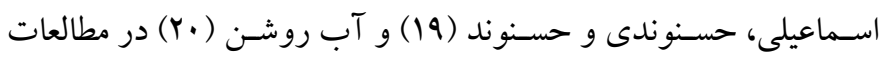

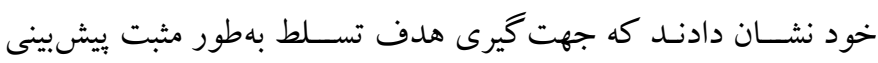

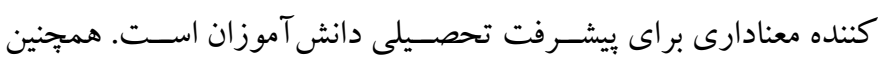

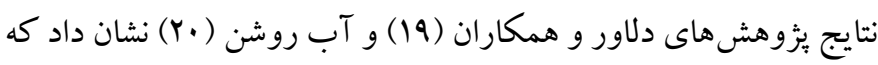
بين جهت گيرى هدف تسـلط با تعامل به محيط كار رقابتى، ارتباط مثبت

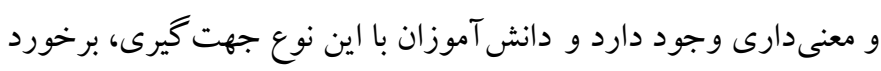

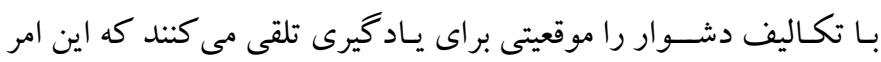
زمينه بهبود عملكرد و افزايش كارايى آنها را فراهم مى آورد.

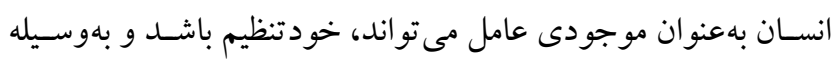

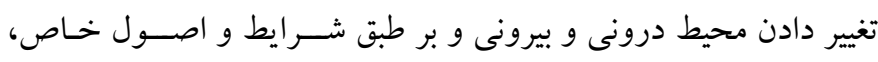

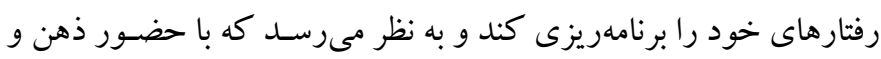

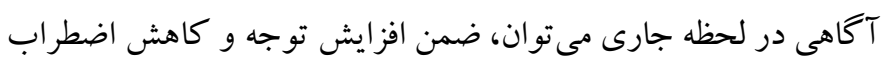

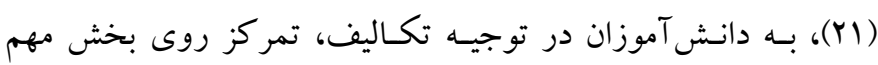

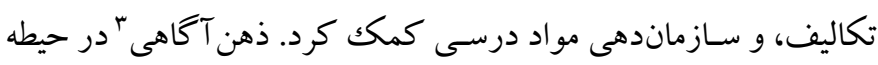
آموزش و ياد گيرى، اسـاس انجام تكليف بهصسورت هشسيار و خودآكاه

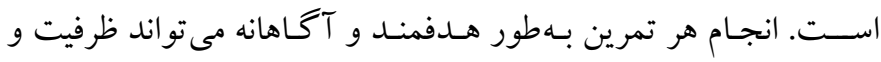

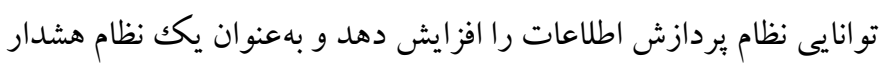

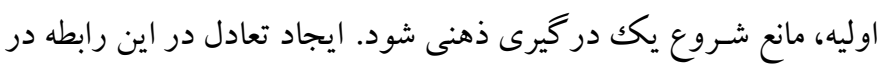

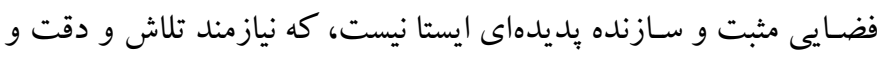

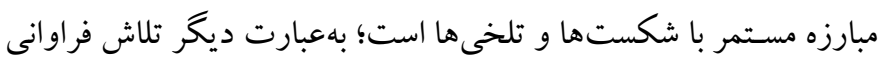

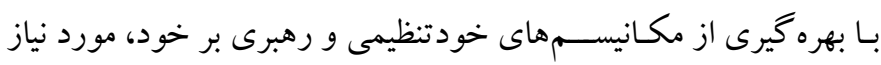
اسـت تا بتوان خود را كموبيش در فضاى روانى و فكرى مثبتى قرار داد. به نظر مىرسد كه شكل گيرى هويت، بهطور مستقيم تحت تأثير ياد گيرى

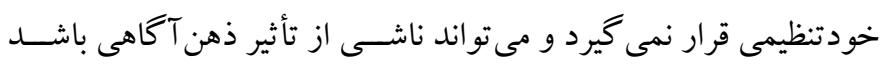

3. Mindfulness
خود تنظيمى'، مؤلفههاى شــناخت، انخيزش، و كنشورى تحصـيلى را

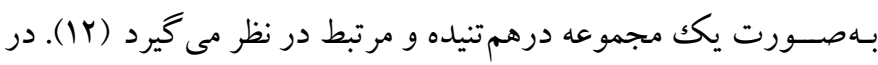

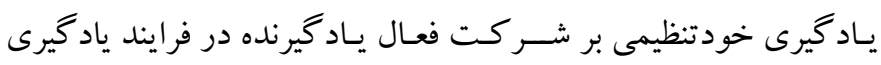

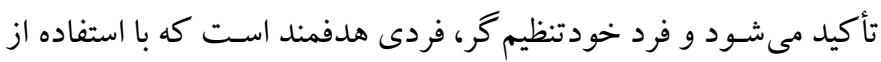

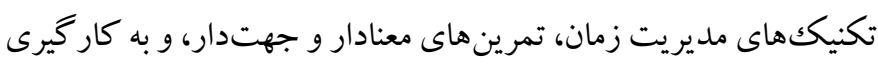

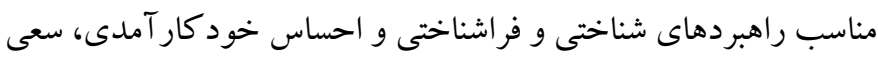

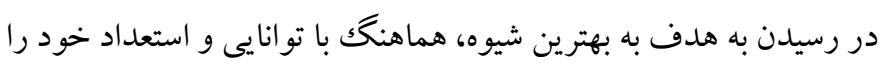

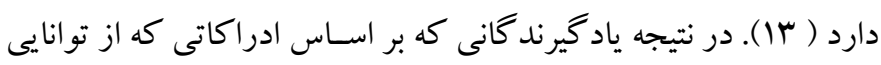

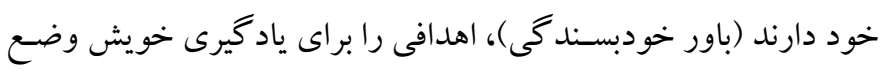

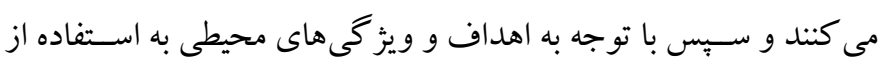

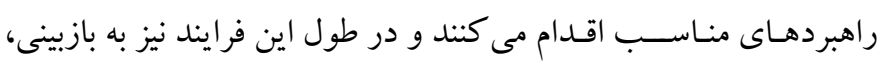

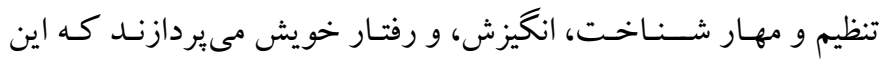

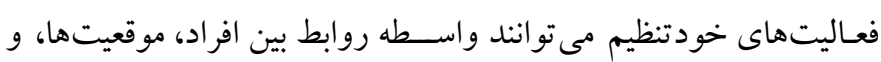
يشرفت كلى آنها باشند (1F).

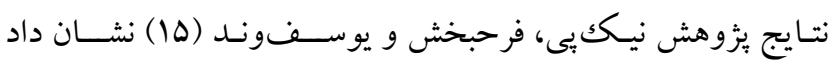

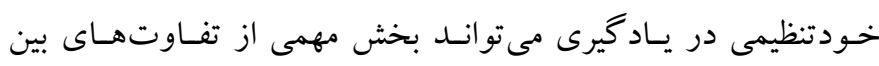

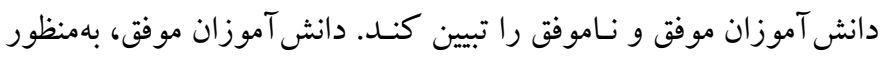

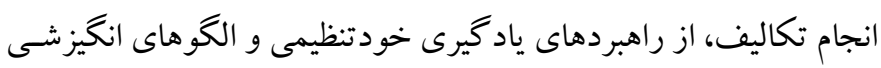
مثل كوشـش براى كســب موفقيت و فعاليتهاى جالش انكخيز و تنظيم

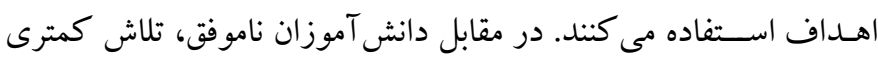

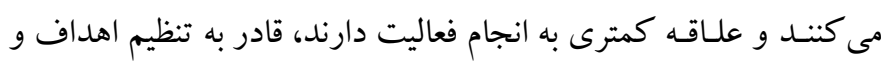

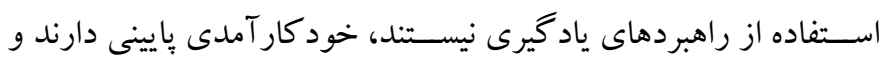

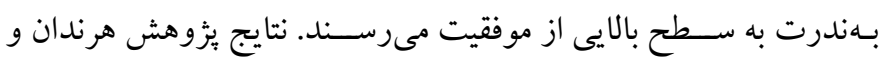

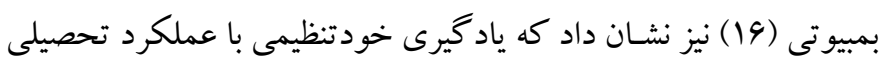

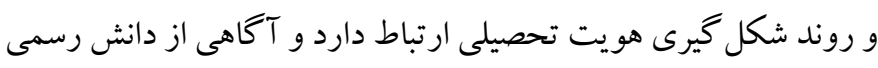

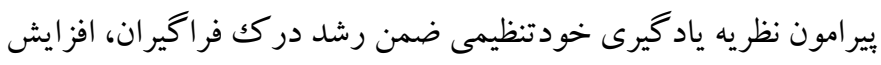
رضايت فردى و بهبود عملكرد ياد گيرى را به همر اه دارد.

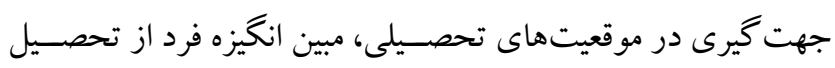

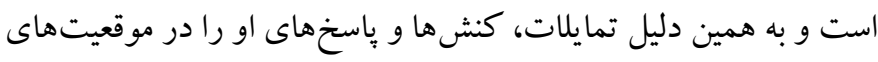

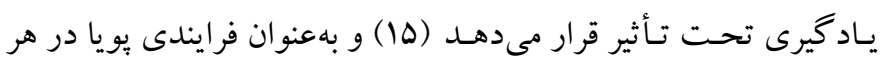




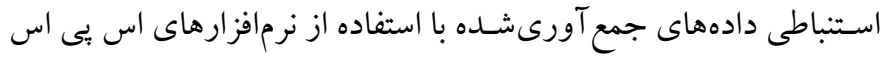

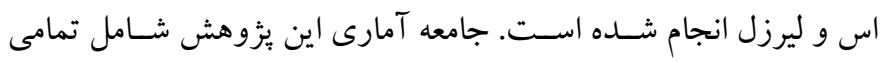

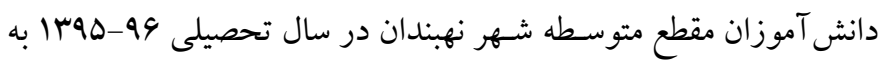

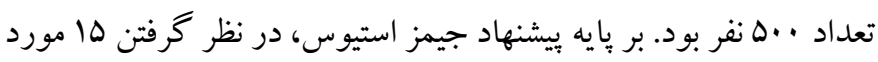

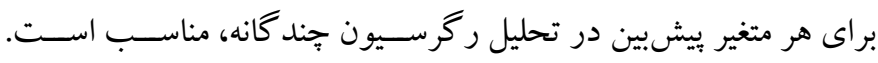

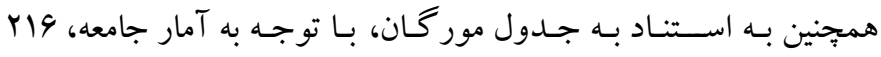
دانش آموز مقطع متوسطه شهر نهبندان به روش نمونه گيرى خوشهاى سه مرحلهاى به عنوان نمونه مورد مطالعه استفاده شد. بر اين اساس ابتدا شهر

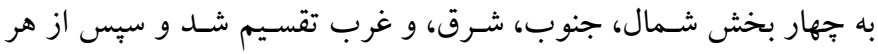

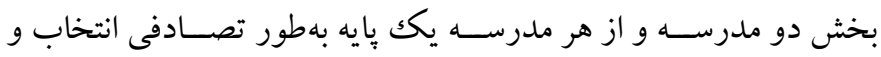

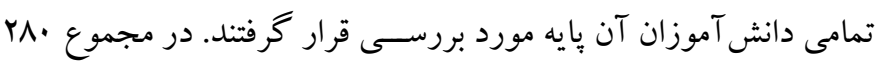

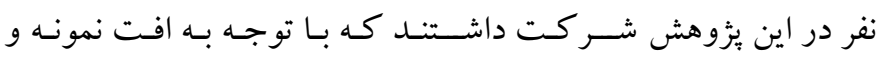

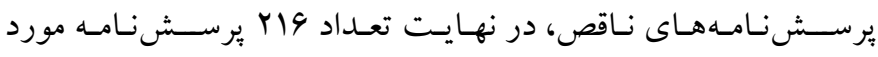

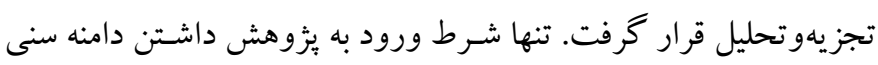

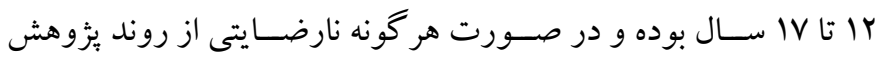
امكان خروج شركت كننده فراهم بوده است. ب) ابزار

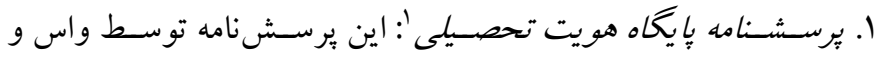

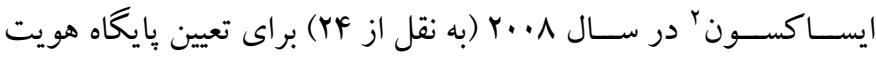

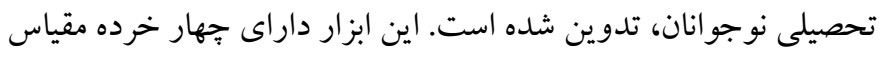

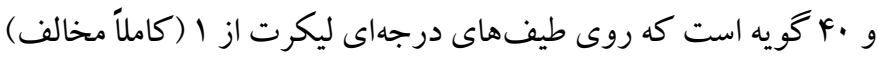

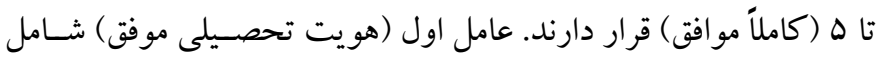
•ا گويه (Fتحصـيلى ديررس) شــامل كويههاى (Y-V-Y

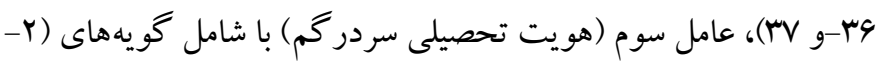
r-1

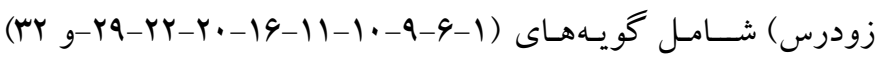
اسـت. آزمودنى يس از خواندن هر سؤ ال مى تواند با انتخاب گز ينه (هيج

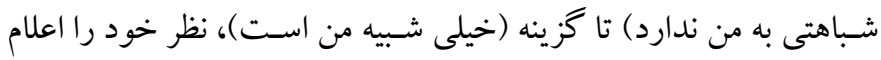

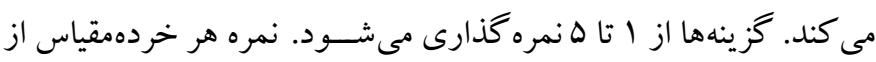

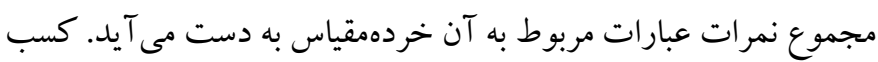

\section{Weas \& Isaacson}

(YY). نتايج يثزوهش هاى كل يور جمر كوهى و محمدامينى (Yr) نشان داد

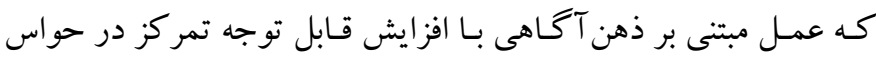

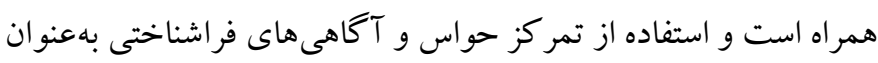
ابزارى براى كمكك به دانش آموزان مى تو اند بسيار مؤثر باشد.

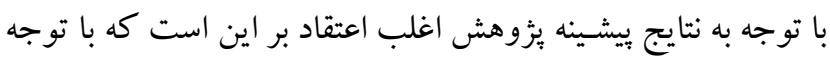

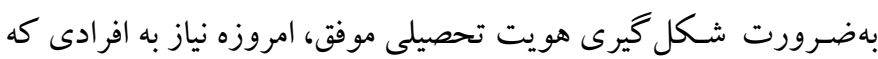

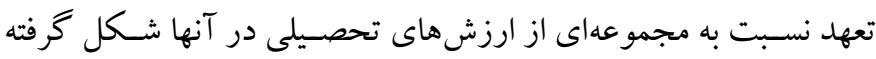

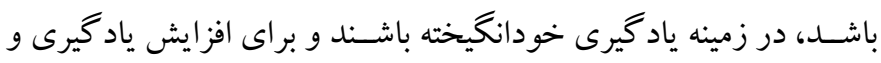

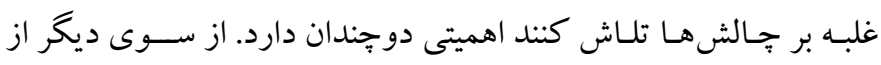
مهم ترين متغيرهاى مؤثر در شـكل گيرى هويت تحصسيلى موفق، مى توان

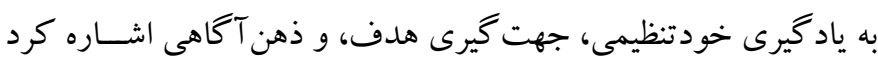

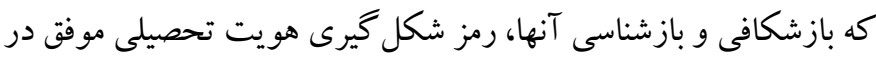

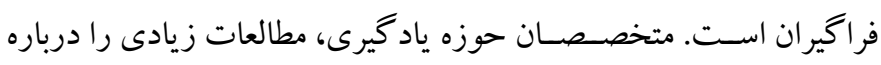

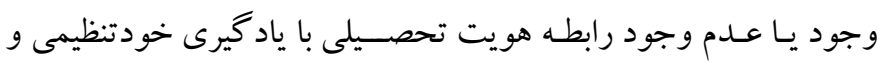

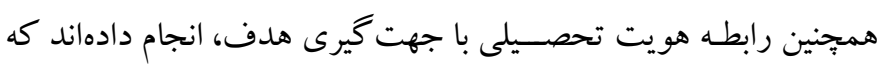

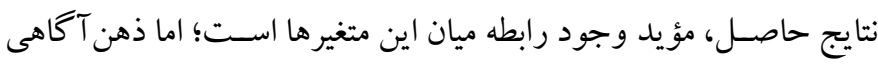

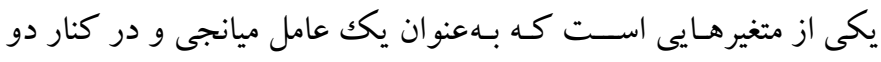

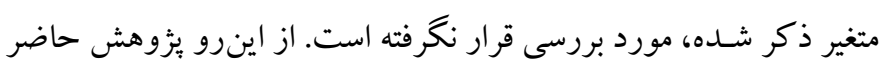

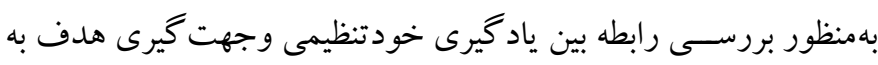
واسـطه گرى ذهن آكاهى با هويت تحصـيلى انجام شــده اسـت و و انتظار

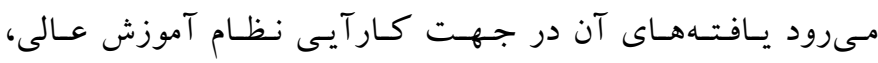

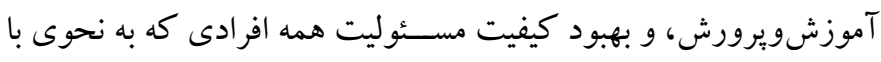

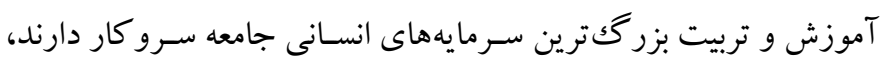
مورد استفاده قرار گيرد.

\section{ووش} الف) طرح هزوهش و شــر كت كنند كان: طرح يزوهش از نظر هدف كاربردى و از نظر روش، همبستخى است كه با شيوه مدلسازى ساختارى

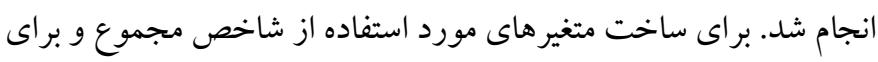
بررسـى فرضــيه يزوهش از روش آمار تحليل عاملى اكتشــافى، تحليل

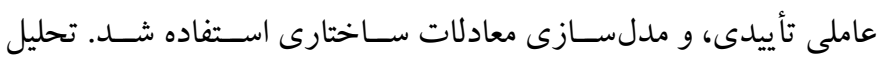




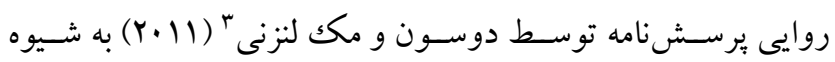

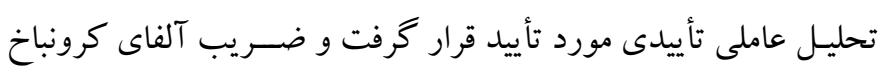

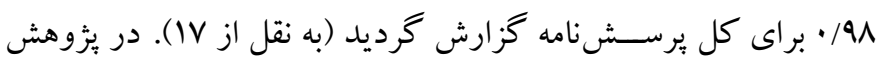

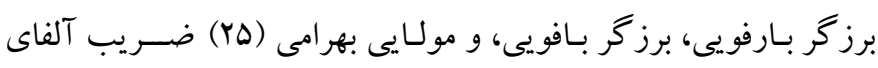

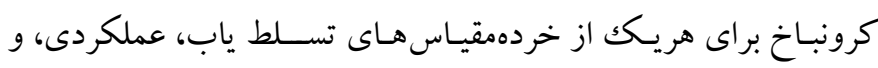

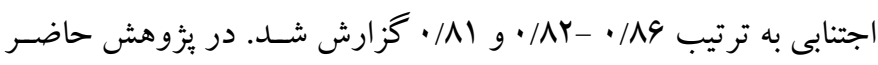

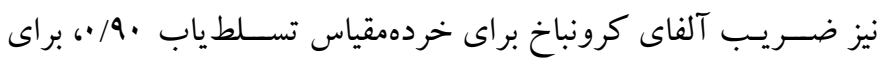

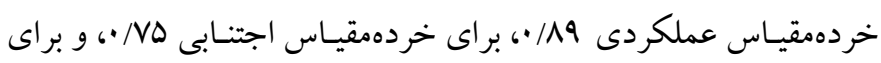

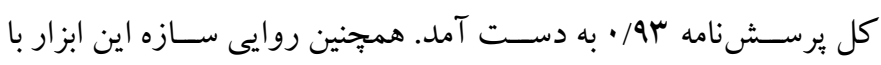

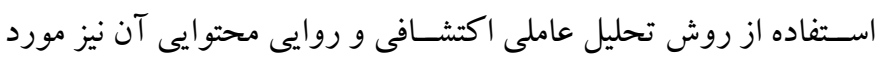

$$
\text { تأييد قرار گرفته است. }
$$

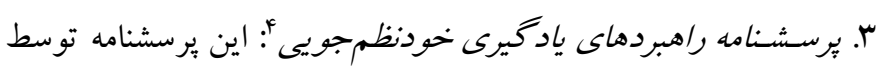

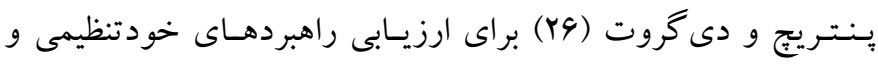

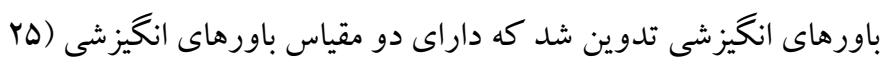

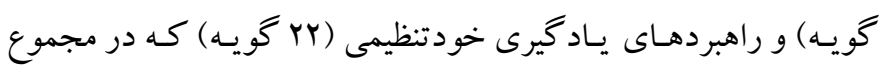

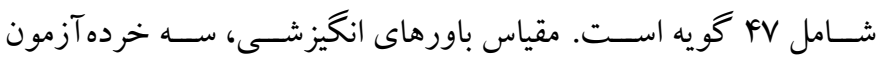

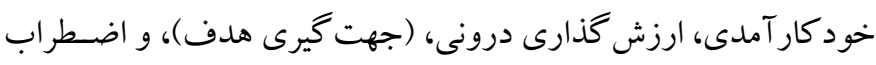

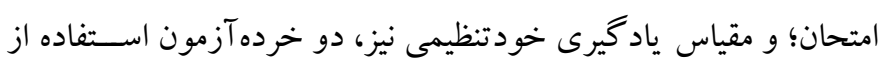
راهبردهـاى شــنـاختى و خودتنظيمى براى مهار شـــاختى (راهبردهاى

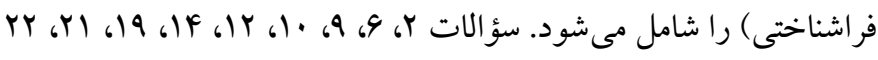

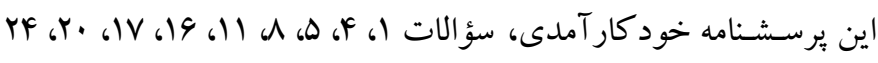

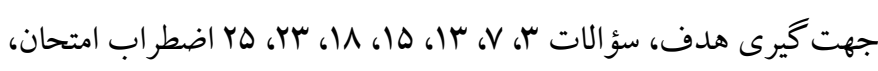

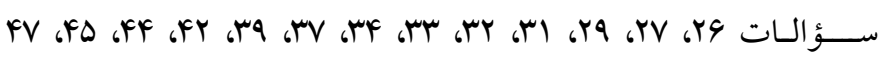

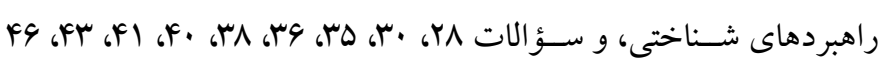

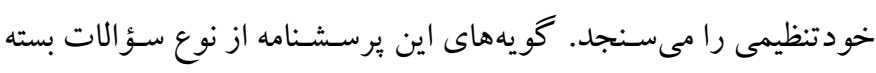

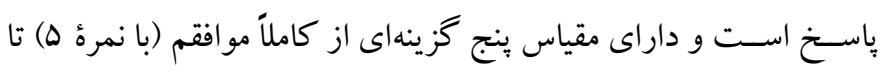

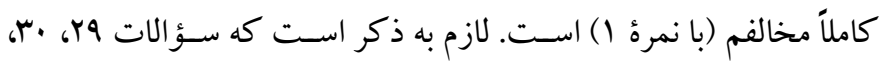

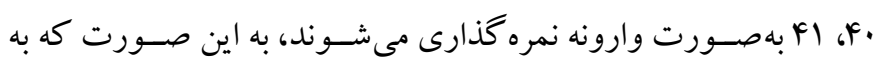

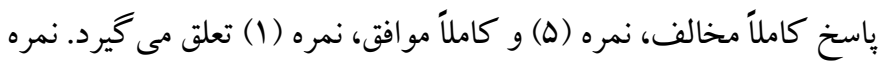

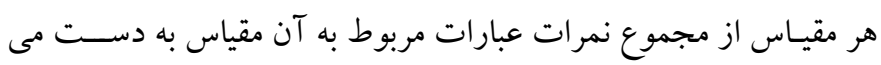

4. Sself-regulated learning strategies - Issues In Educational Research-
نمره بالا در هر خردهمقياس، بيان كننده نوع هويت تحصسيلى شكل گرفته در فرد است. حداقل نمره در هر خرده مقياس •الو حداكثر •هاست.

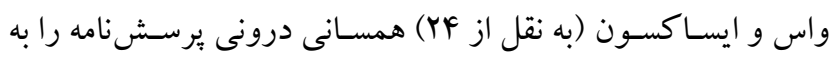

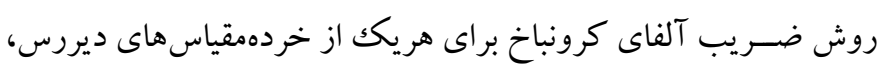

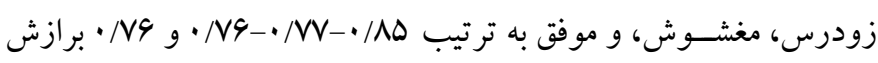

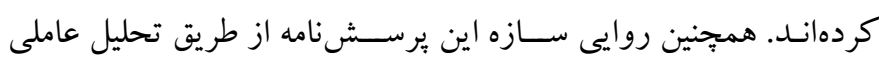

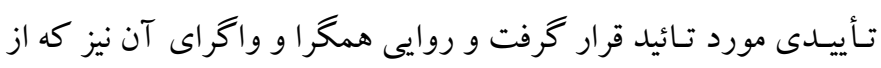
طريق تعيين همبسـتخى منزلت هاى هويت تحصيلى با سـبك هاى هويت

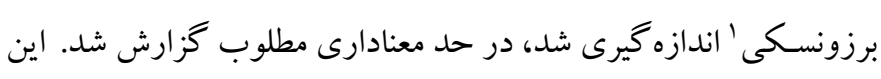

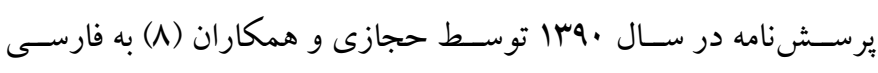

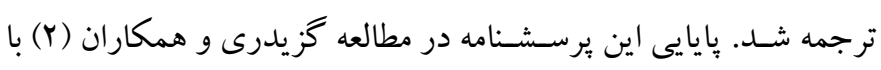

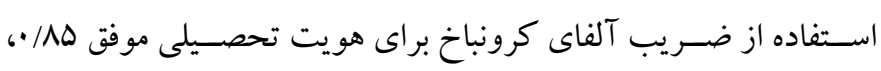

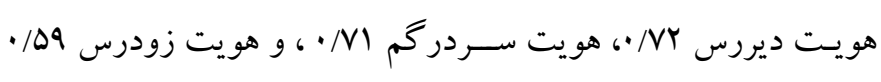

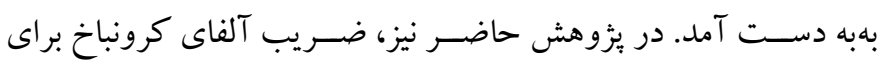

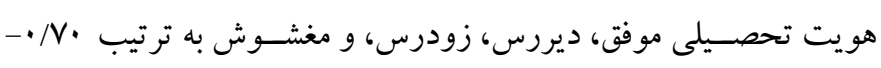

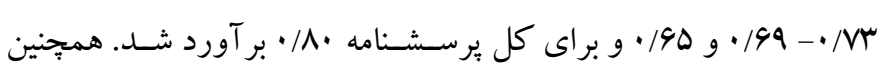

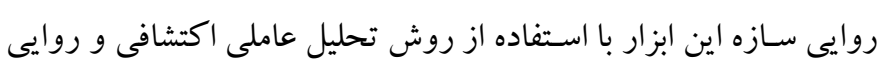
محتو ايى آن نيز مورد تأييد قرار كرفته است.

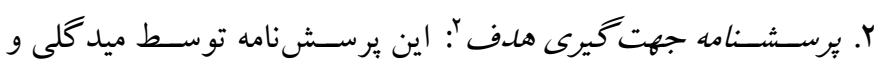

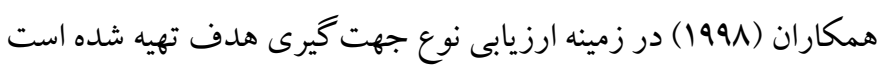

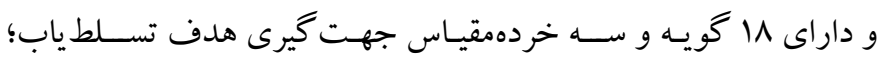

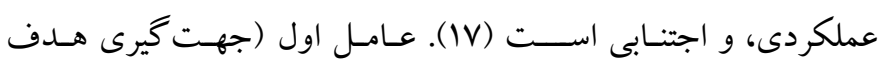

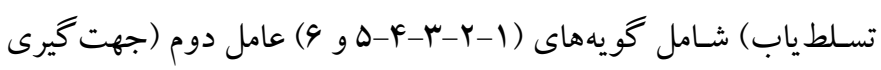

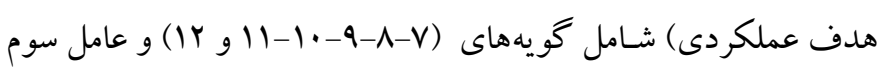

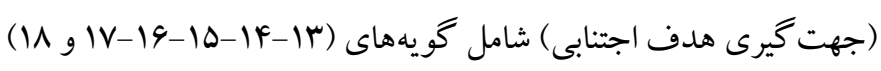

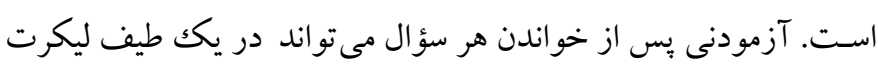

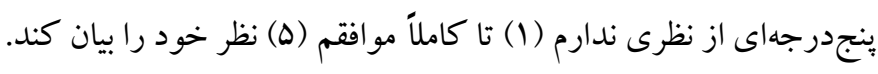

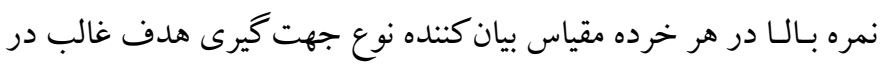

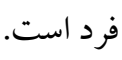

1. Berzonski

2. The Goal Orientations Scale

3. Doson Maklenzi 


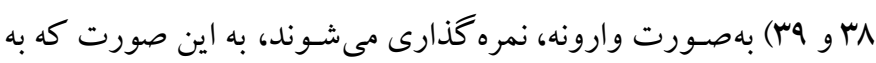

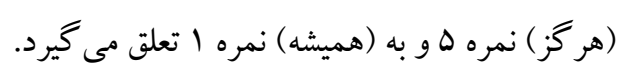

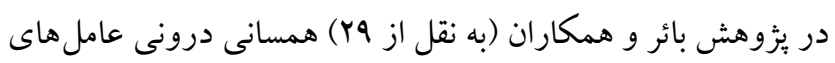

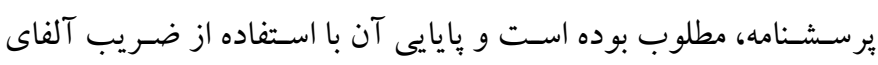

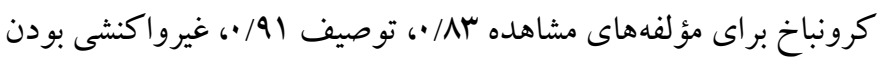

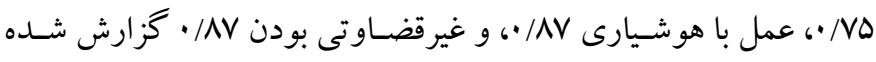

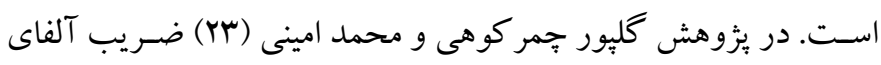

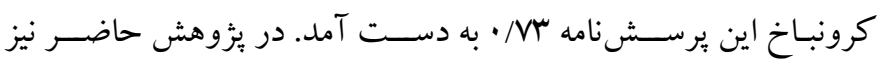
ضريب آلفاى كرونباخ براى مؤلفهاى غيرواكنشى، توصيف، مشاهدها،

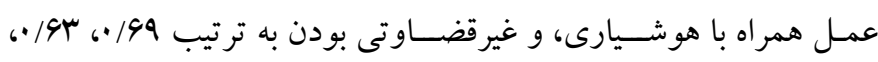

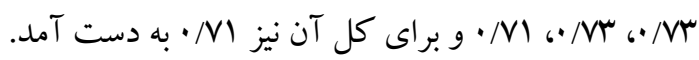

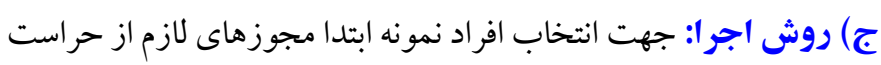

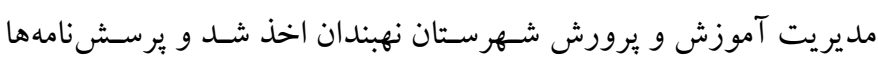

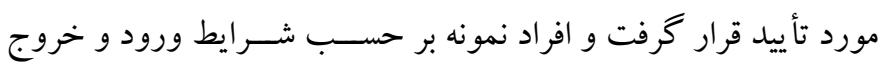

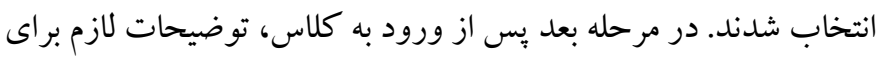

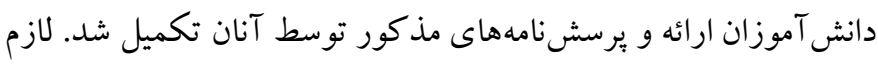

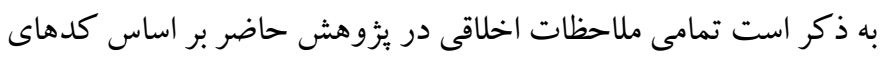

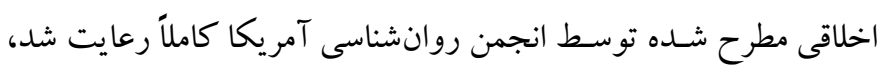

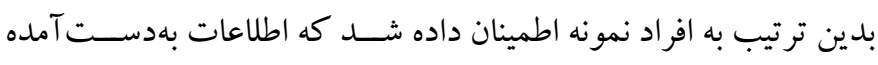
بهصورت جمعى جهت انجام كار بزٔوهشى مورد تحليل قرار مى گيرد و

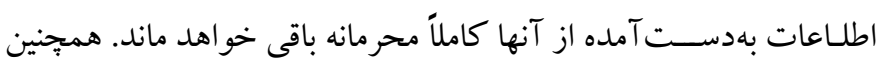

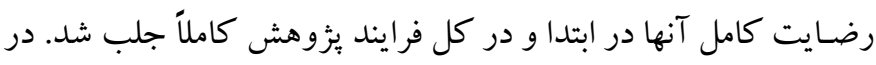

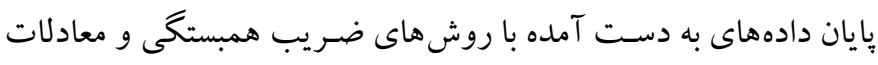

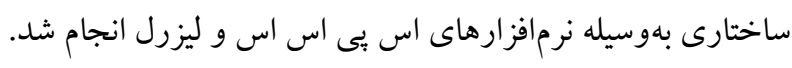

\section{يافته ها}

مقادير شــاخصهاى توصـيفى براى متغيرهاى مربوط شــامل ميانخين،

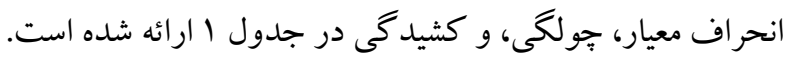

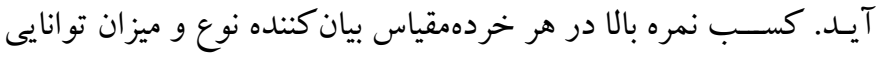
فرد در فرايند خودتنظيمى در ياد گيرى است.

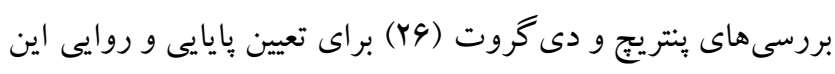

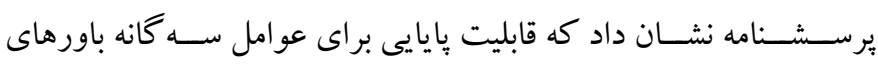

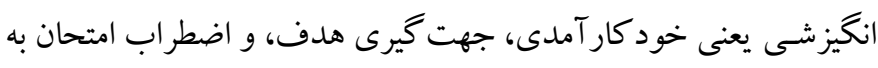

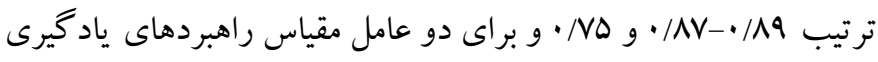

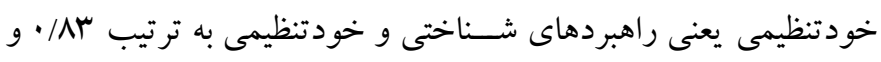

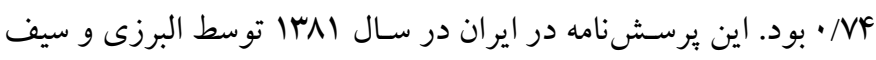

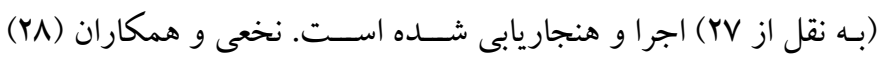

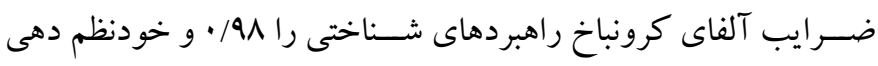

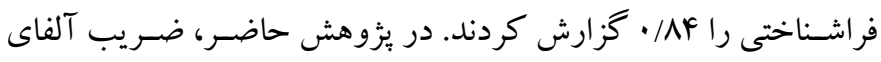

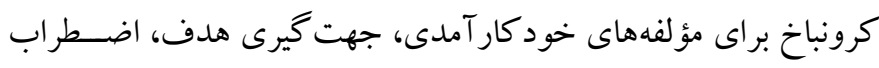

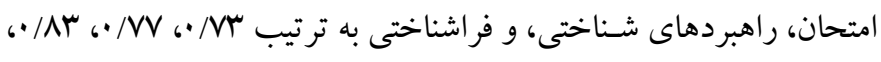

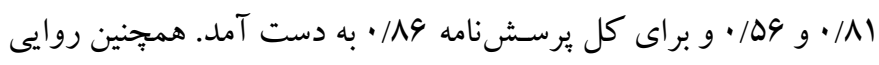

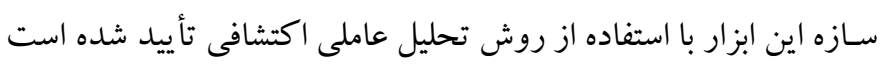

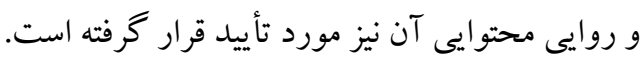

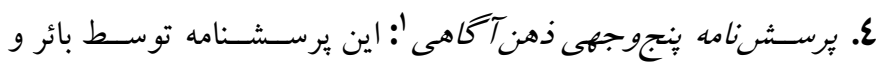

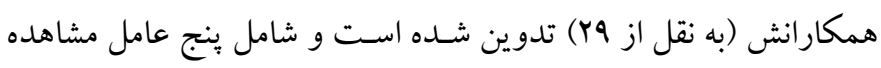

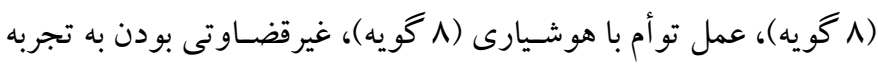

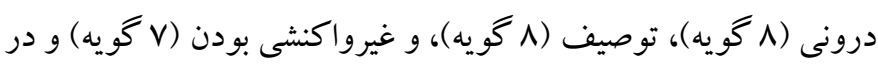

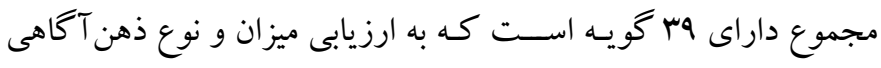

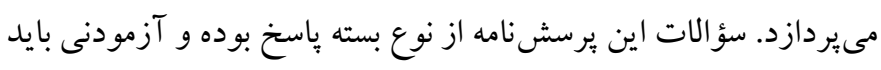

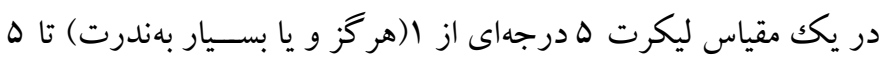

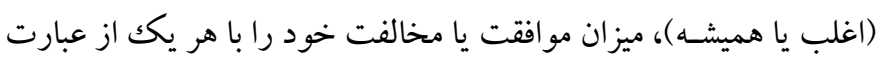

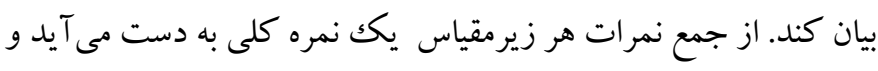

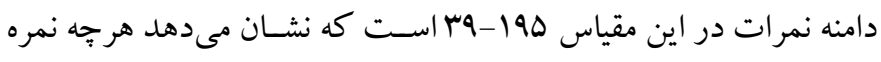

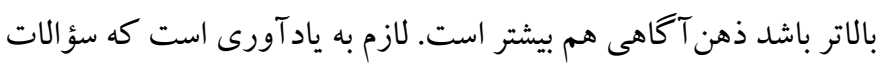
(T) 


\begin{tabular}{|c|c|c|c|c|}
\hline كشيدكى & جولكى & انحراف معيار & ميانكين & ابعاد \\
\hline$\cdot / \wedge$. & $\cdot / \Delta r$ & $1 \cdot / 4 \mathrm{~V}$ & $1 \% / \pi 9$ & هويت تحصيلى \\
\hline 每 & $\cdot /{ }^{*} \wedge$ & १/৭० & $\mid r / T F$ & ذهن آكاهى \\
\hline$\cdot / \mathrm{VA}$ & .199 & $1 . / 11$ & $\mid r / \Delta F$ & ياد گيرى خو دتنظيمى \\
\hline .194 &.$/ \Delta F$ & $.1 / 1$. & $\mid r / . \Delta$ & جهت گيرى هدف \\
\hline
\end{tabular}

\begin{tabular}{|c|c|c|c|c|}
\hline$\varepsilon$ & $r$ & $r$ & 1 & متغيرها \\
\hline & & & 1 & ا. ياد گيرى خودتنظيمى \\
\hline & & 1 & $\cdot, r q$ & r. جهت گيرى هدف \\
\hline & 1 & $\cdot, 1 \wedge$ & • & r. ذهن آكاهى \\
\hline 1 & $\cdot, r F$ & $\cdot$, , & $\cdot, \Delta r$ & F. هويت تحصيلى \\
\hline
\end{tabular}

با توجه به نتايج جدول ץ ياد گيرى خود تنظيمى، جهت گيرى هدف،

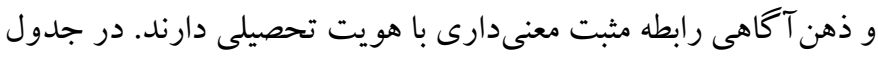

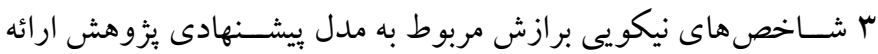

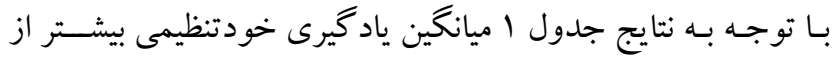

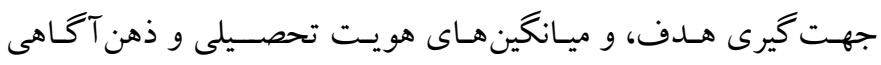

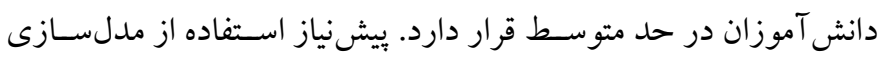

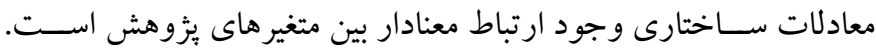

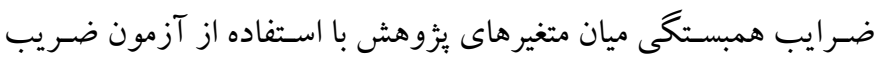
همبستخى بيرسون در جدول ب بررسى شده است.

جدول ": شاخصهاى نيكويى برازش مربوط به مدل نقش ميانجى كرى ذهن آكاهى در رابطه بين يادكيرى خودتنظيمى، جهت كيرى هدف، و هويت تحصيلى

\begin{tabular}{|c|c|c|}
\hline مقدار كزارششده & حد مطلوب آماره & شاخص \\
\hline .1 .94 & $\leq \cdot / \cdot 1$ & ريشه ميانگين توان دوم خطاى تقريب (RMSEA) \\
\hline T/ATV & كمتر از r & نسبت خددو X /df \\
\hline.$/ 9.1$ & $\geq \cdot / 9$. & برازندگى (GFI) \\
\hline.$/ Q \Delta F$ & $\geq \cdot / 9$. & برازندگى تعديل يافته (AGFI) \\
\hline$\cdot / \wedge 99$ & $\geq \cdot / 9$. & برازش مقايسهاى (CFI) \\
\hline.$/ a v e$ & $\geq \cdot / 9$. & برازش نرم (NFI) \\
\hline . /9YD & $\geq \cdot / 9$. & برازش غير نرم (TLI) \\
\hline . & $\geq \cdot / 9$. & برازش افزايشى (IFI) \\
\hline
\end{tabular}

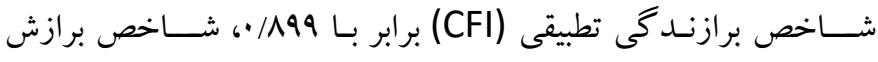

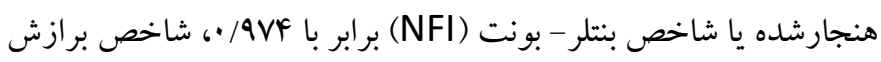

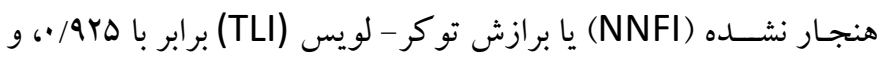
مقدار شـاخص برازش افزايشى (IFI) برابر با اسوه/• است، مىتوان نتيجه

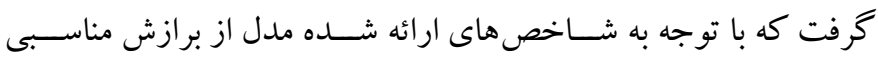
برخوردار اسـت. در نتيجه با توجه به مبانى نظرى و شـاخص هاى بـ بر ازش

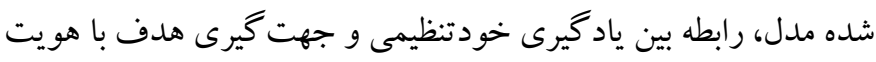

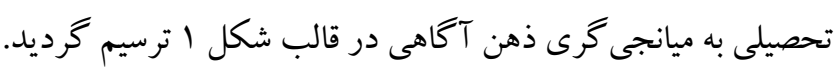

بـا توجـه به اينكه شــاخص ريشـهـ ميانگين توان دوم خطاى تقريب

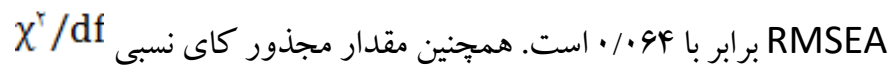

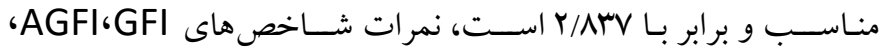
بين صـفر تا يكك متغير اسـت (نمرات CFI ،IFI ،TLI ،NFI،RMSEA مذكور هر جه به يكك نزديكك تر باشـــ نشـاندهندة برازش مناسـب مدل

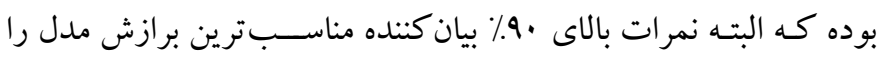

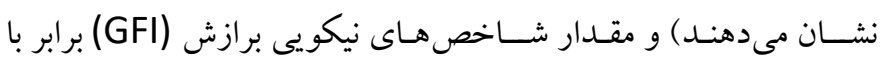

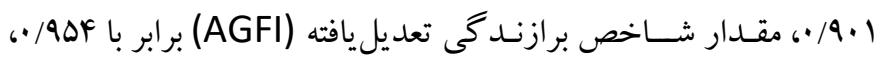




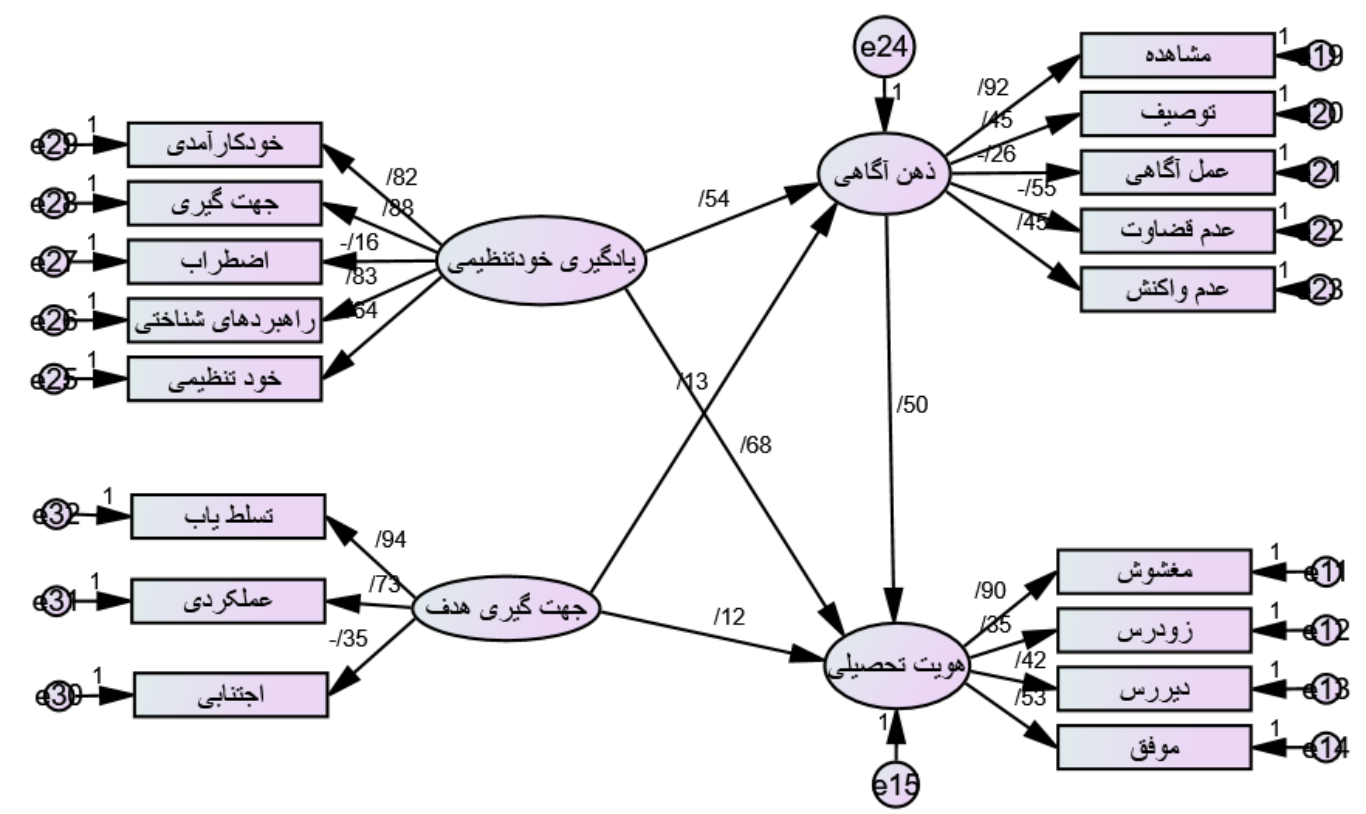

شكل ا: مدل نقش ميانجى كرى ذهن آحاهى در رابطه بين يادكيرى خودتنظيمى و جهت كيرى هدف با هويت تحصيلى در دانش آموزان

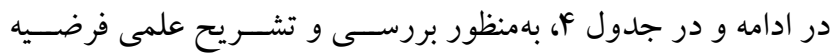
تحقيق، به بررسى ضريب مسير و معنادارى رابطهى ميان متغيرها برداخته

جدول ع: ضريب مسير و معنى دارى آن و بررسى فرضيههاى تحقيق

\begin{tabular}{|c|c|c|c|c|}
\hline نوع رابطه & p-مقدار & t & ضريب مسير & رابطه موردبررسى \\
\hline افزايشى & $\cdots$ & $\mid r / N r^{* * *}$ & $\cdot / \Delta \cdot g \cdot / \Delta F$ & ياد گيرى † ذهن آكاهى كهويت تحصيلى \\
\hline افزايشى & $\ldots$ & 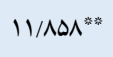 & & 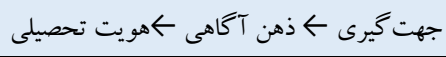 \\
\hline
\end{tabular}

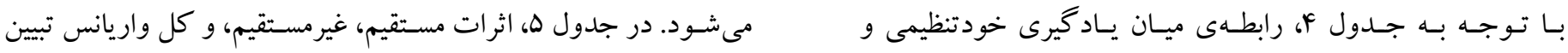

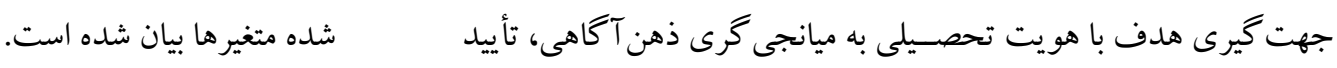

جدول 0: نتايج مربوط به اثرات مستقيم، غيرمستقيم و كل واريانس تبيين شده متغيرها

\begin{tabular}{|c|c|c|c|c|}
\hline واريانس تبيين شده & اثر كل & اثر غيرمستقيم & اثر مستقيم & مسير \\
\hline \multirow{5}{*}{.$/ 11$} & & & & بر هويت تحصيلى از \\
\hline &.$/ \Delta$ & - &.$/ \Delta$ & ذهن آكاهى \\
\hline & $\cdot, 90$ & $\cdot / \mathrm{TV}$ & $\cdot 191$ & ياد كيرى خود تنظيمى \\
\hline & $\cdot / 1 \wedge$ & $\cdot, 4$ & $\cdot / r$ & جهت گيرى هدف \\
\hline & & & & بر ذهن آكاهى از \\
\hline \multirow{2}{*}{.$/ 11$} & $\cdot / \Delta F$ & - & $\cdot / \Delta F$ & ياد كيرى خود تنظيمى \\
\hline & $\cdot / 1 r$ & - & $\cdot / 1 r$ & جهت گيرى هدف \\
\hline
\end{tabular}


و جهـت گيرى هـدف بر ذهن آكـاهى بـه ترتيـب

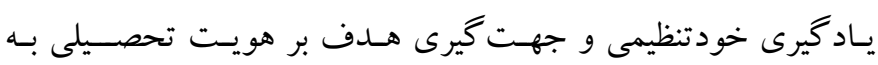

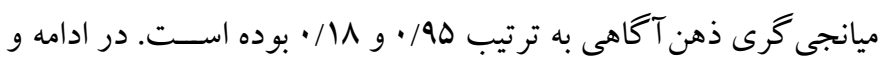

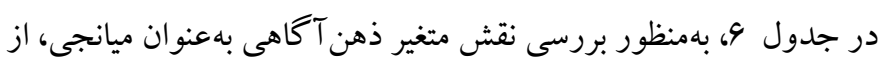

بوت استر إٍ استفاده شد.
با توجه به نتايج جدول ه، ياد گيرى خودتنظيمى و جهت گيرى هدف

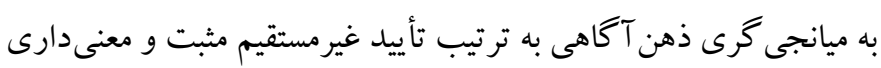

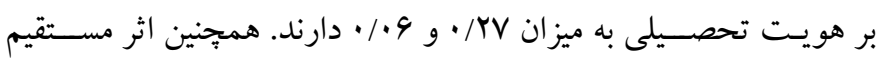

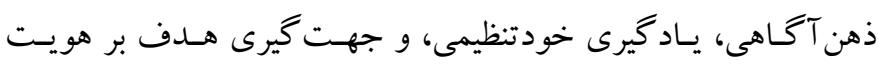

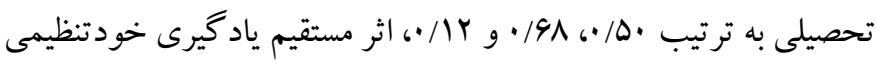

جدول ج: ضريب مسير و معنى دارى بوت استراب و بررسى نقش متغير ميانجى

\begin{tabular}{|c|c|c|c|c|}
\hline p-value & حد بالا & حد بايين & bootstrap & 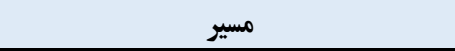 \\
\hline.$/ 4$ &.$/ 11$ & .1 .4 & $.1 \cdot 9$ & يادگيرى † ذهن آكاهى † هويت تحصيلى \\
\hline$\cdot / \cdot r$ & $\cdot / \mathrm{r}$ & $\%$ & $\%$ & جهت گيرى † ذهن آكاهى ک هويت تحصيلى \\
\hline
\end{tabular}

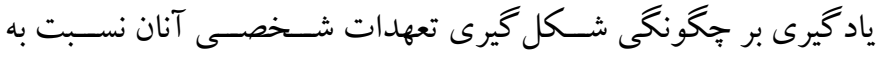

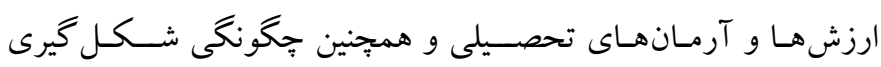

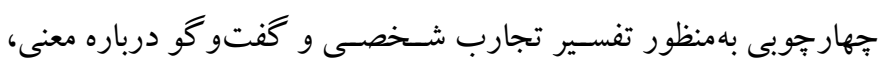

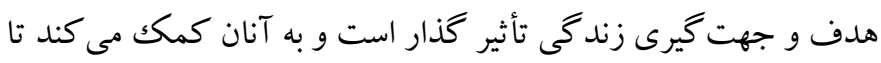

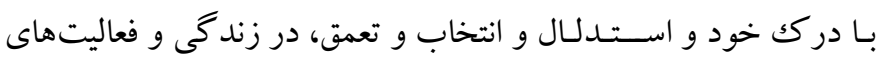

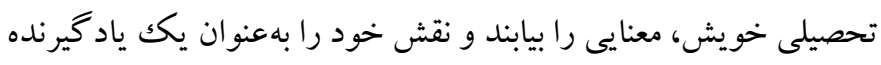
واقعى بيذيرند.

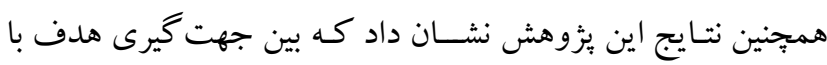
هويت تحصيلى رابطه مستقيم و معنادارى وجود دارد و اين نتيجه با نتايج

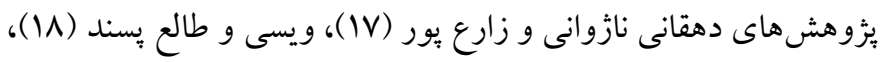

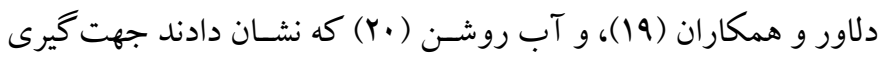

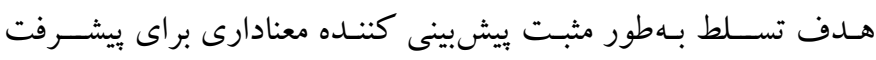

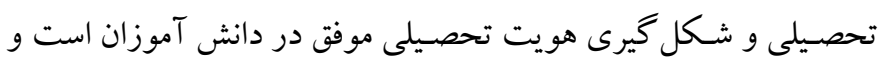

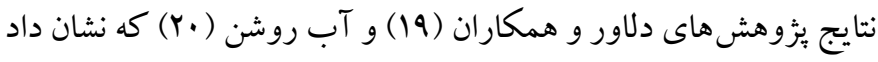

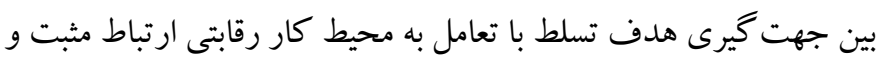

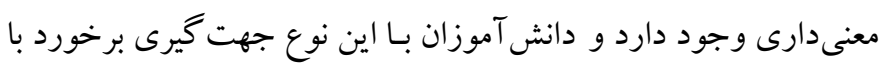
تكاليف دشـوار را موقعيتى براى ياد كيرى تلقى مى كنند و همين مســــله

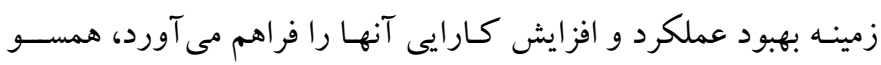

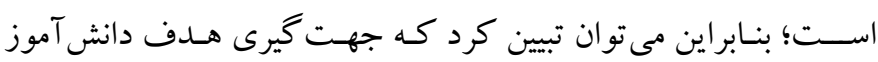

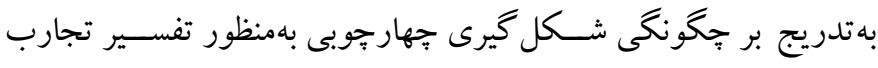

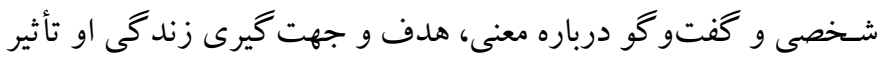

با توجه به قرار نخر فتن صفر در فاصله اطمينان، مىتوان نتيجه گرفت

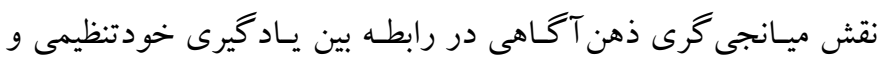

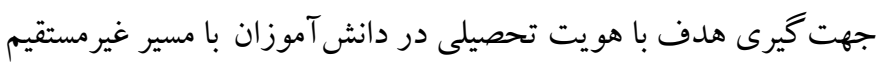

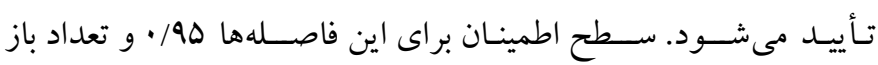
نمونه گيرى ... إست

\section{بحث و نتيجه تيرى}

اين يثزوهش با هدف بررسـى رابطه ياد گيرى خود تنظيمى و جهت گيرى

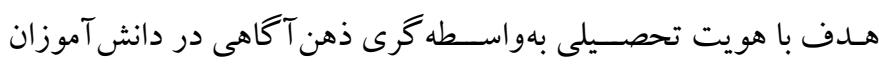

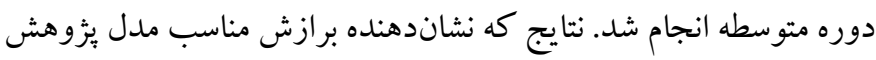

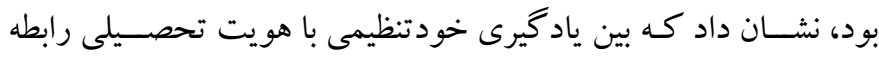

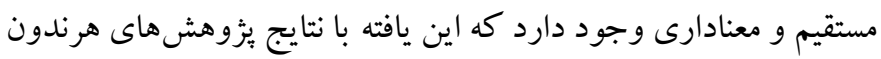

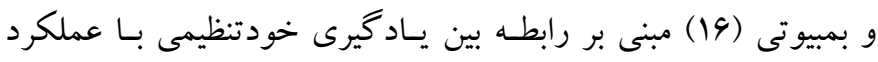

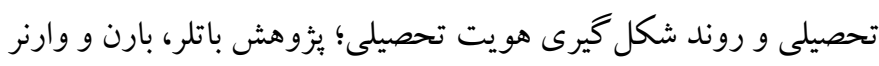
(9) و عبـاس و البحرانى ( •1) مبنى بر ارتبـاط مثبـت و معنسادار بين

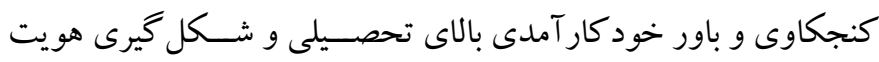

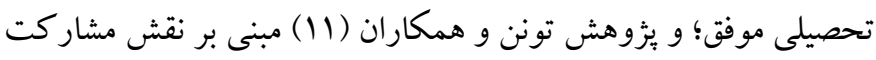

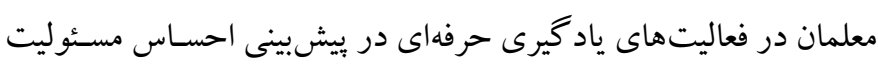

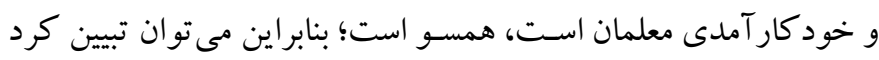

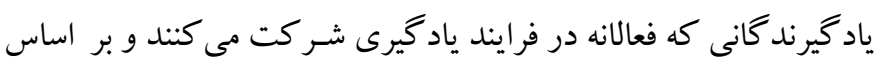

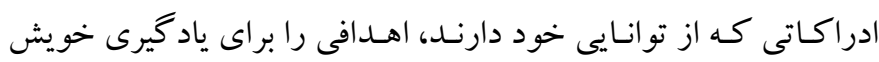
وضع مى كنند و سبس با تو جه به اهداف و ويز گى هاى محيطى به استفاده

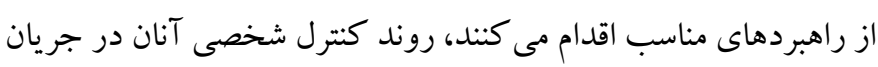


مى كنند، و بر اسـاس ادراكاتى كه از توانايى خود دارند، اهدافى را براى

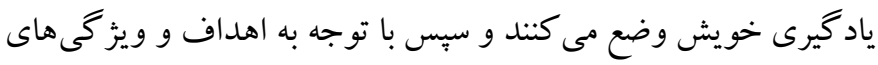

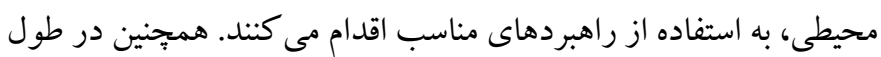

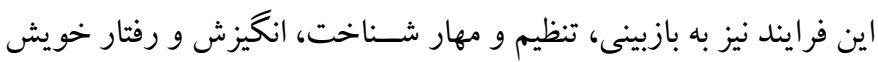

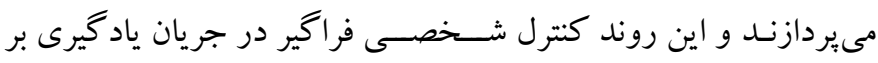

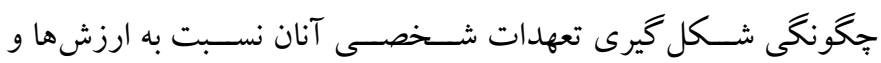

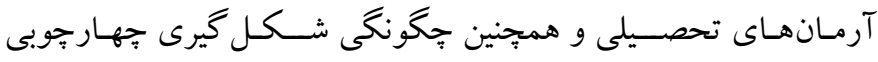

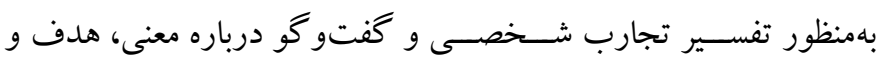
جهت گيرى زندگى، تأثير گذار است.

بر اسـاس نتايج به دست آمده در اين يزووهش لازم است كه استادان، معلمان، و متصديان تعليم و تربيت، در جهت هدايت فراگيران به استفاده

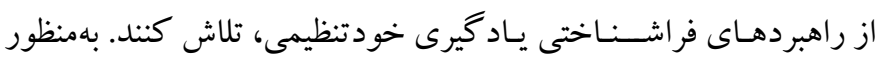
اتخـاذ هـدف مـذكور و هدايت تمامى فراكيران در اين جهت يـيشــنهاد

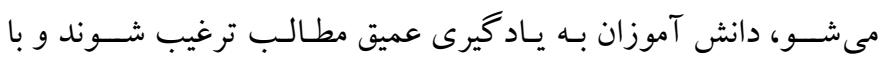

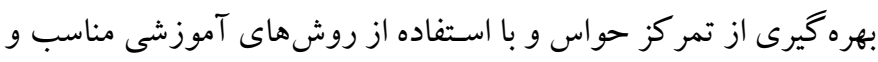

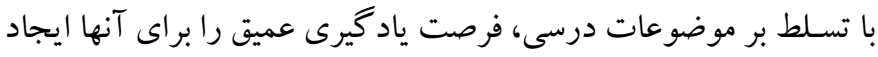

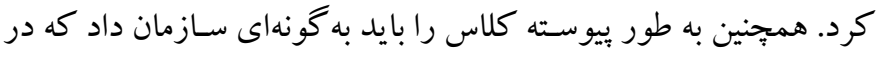

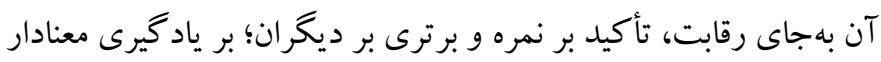

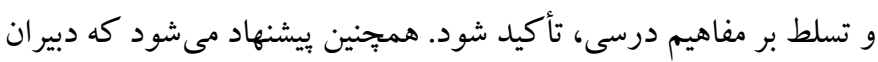
و متخصصان تعليم و تربيت، موضوعات درسى را بهصورت سازماندهى

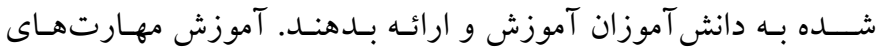

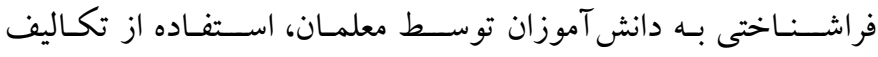

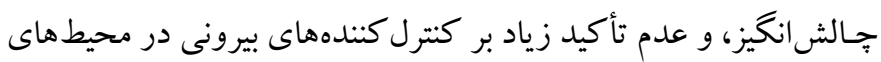

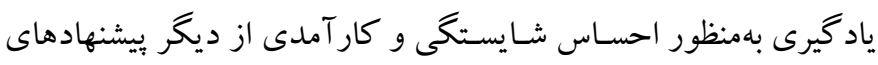

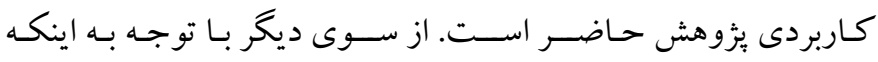

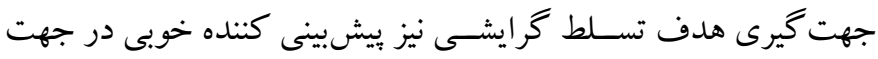
شـكل گيرى هويت تحصـيلى موفق اسـت، بيشــنهاد مى شـود دسـتهاى از

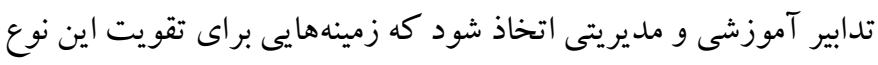

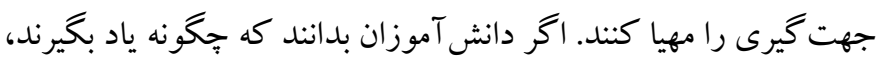
علاقه و رغبت بيشـترى به تحصسيل و مطالعه بيدا مى كنند. اطللاع از شـيوه

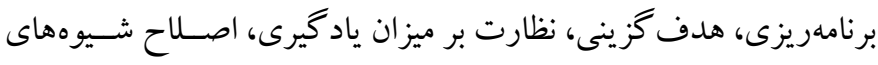

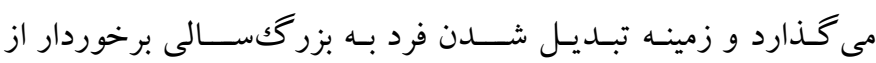
خوديندارى منسجم و نقشى ارزشمند در اجتماع را فراهم مى آورد.

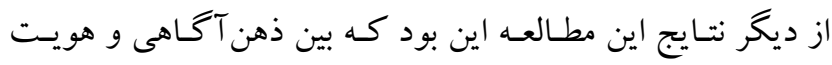

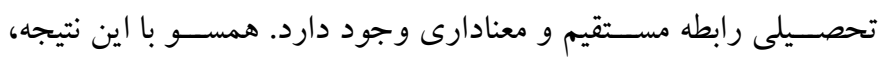

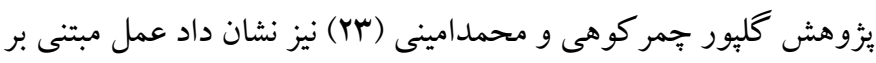

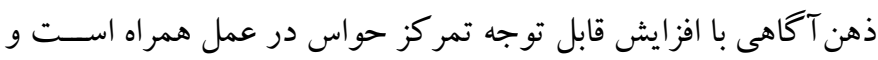

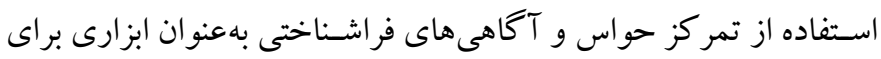

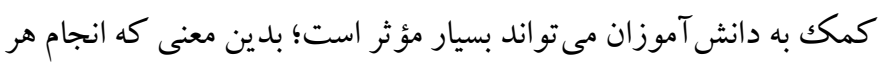

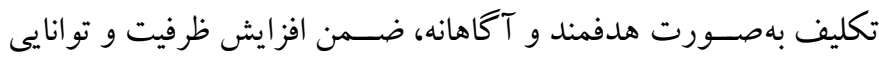

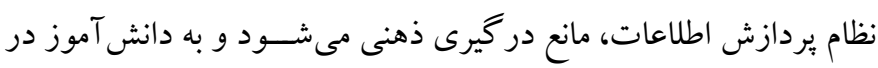
توجيه تكاليف، تمركز روى بخش مهم تكاليف و مو اد درسى، و تأمل و

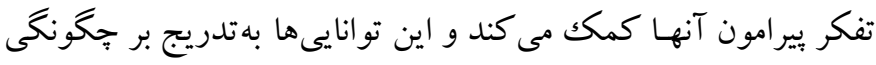

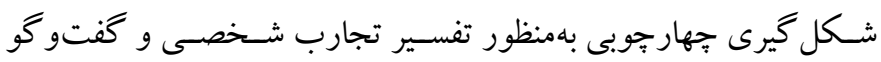

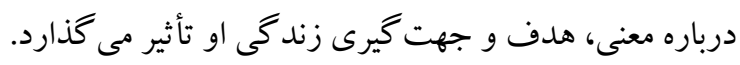

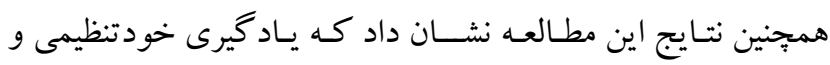
جهت گيرى هدف به واسـطه گرى ذهن آكاهى بر هويت تحصسيلى تأييد

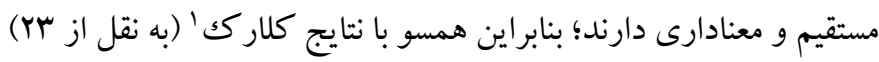

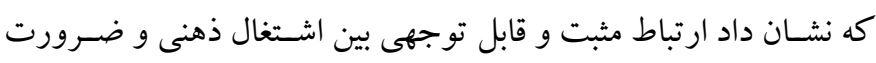

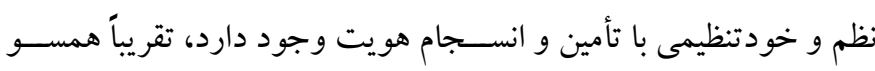

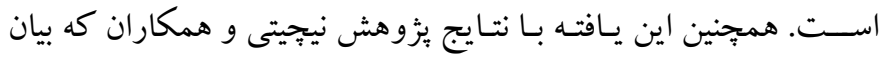

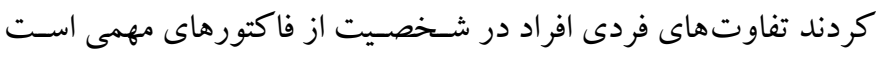

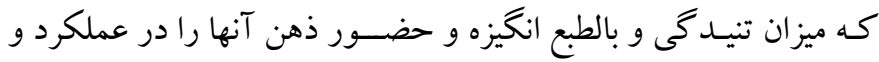

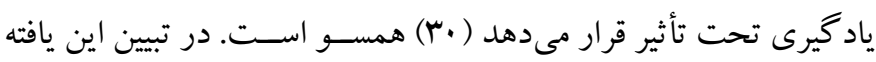
مى توان بيان كرد نوع اهدافى كه دانش آموزان در زمينه تحصيلى انتخاب

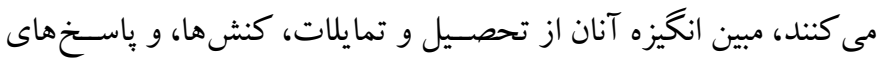
آنان در موقعيتهاى تحصـيلى اسـت كه آنان را در به بايان رســاندن موفقيت آميز يكك تكليف و دستيابى به درجه معينى از شايستخى در كار، تهاء

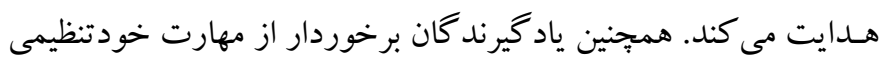

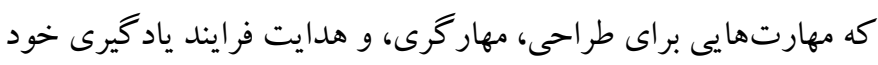

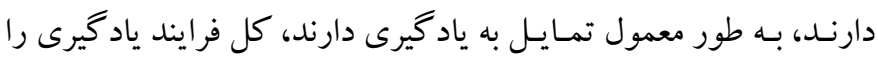

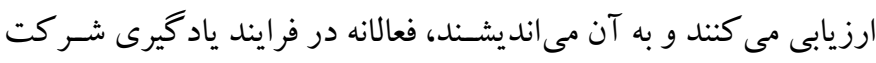

\section{Kelark}


تشكر و قدردانى: اين مقاله نتيجه مطالعهاى اسـت كه توسط فرزانه يوسفى

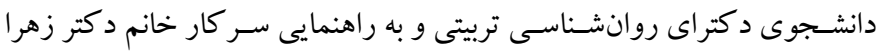

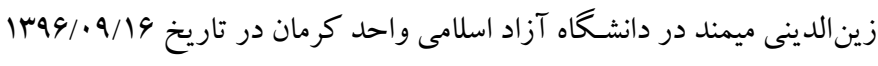

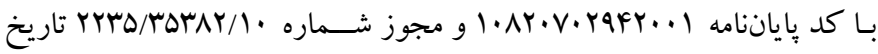

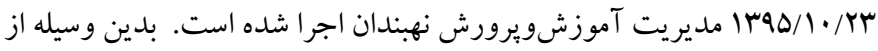

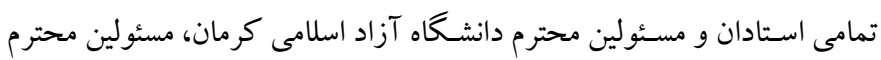

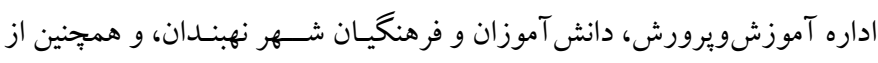

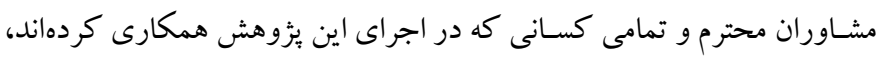
صميمانه تشكر و قدردانى مى شود.

تضاد منافع: نويسند كان مقاله هيج گونه تعارض منافع را در گز ارش يافتهاى

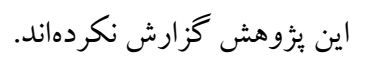

ياد گيرى و مطالعه، و نظمدهى باعث مى شـوند كه دانش آموزان عملكرد بهترى داشته باشند و موضوع به افزايش انخيزه بيشرفت منجر خو اهد شد وند

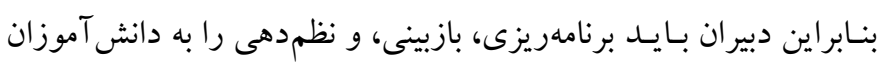
آموزش دهند و خود الكويى عملى براى آنان باشند.

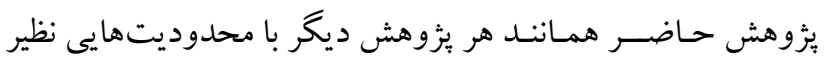

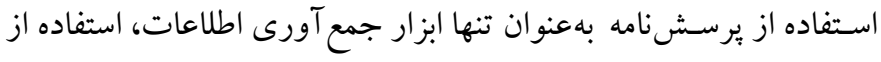

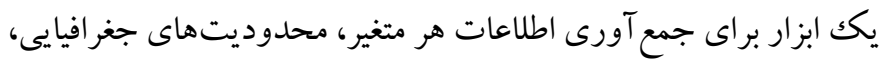

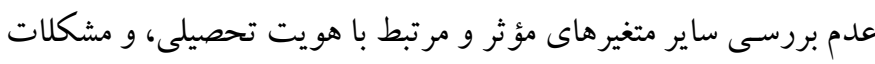

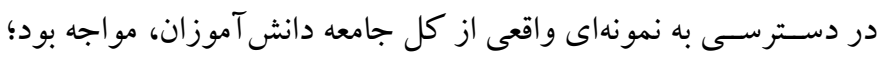
بنابر اين ييشـــهاد مى شــود در يزوهش هاى بعدى، رابطه سـاير متغيرهاى

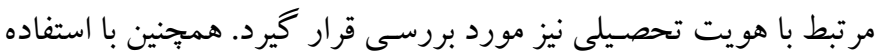

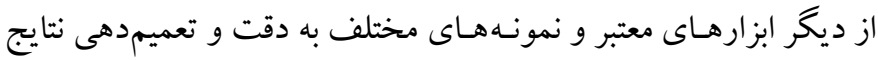




\section{References}

1. Farjami H. Necessity of educational identity development for sustainable foreign language learning. Magazine Grow Language. 2014; 107: 4-11. [Persian]. [Link]

2. Gazidari E, Gholamali Lavasani M, Ejei J. The relationship between academic identity and selfregulation learning strategies with academic procrastinate students. Journal of Psychology. 2016; 19(4/76): 346-362. [Persian]. [Link]

3. Faramarzi H, Maktabi G, Ghasemi S, Farzadi F. The examination of the relationship between motivational orientations and academic self- determination with academic identity among joundishapor students in Ahvaz. Educational Development of Judishapur. 2016; 7(4): 346-354. [Persian]. [Link]

4. Badeleh A, Toomaj A. Structural equations of relationships between learning disorder, emotional intelligence and depression in primary school students. Quarterly Journal of Child Mental Health. 2018; 4(4): 59-70. [Persian]. [Link]

5. Yousefi F, Zeinaddiny meymand Z, Razavi Nematollahi V, Soltani AA. The role of educational identity and objectives orientation in forecasting the metacognitive strategies of self-regulatory learning. Scientific Journal of Education Research. 2018; 13(53): 131-161. [Persian]. [Link]

6. Shokohi Nasab M. Study of relationship between goal orientation and independence with educational identity in fourth grade high school students in Sirjan city [Master's Thesis]. [Yazd, Iran]: Faculty of Literature and Humanities, Yazd University; 2013, pp: 57-72. [Persian].

7. Yosefi F, Zeinadini Z, Razavi V, Soltani A. The role of mediation of mind-consciousness components in relation between different types of goal orientations with four-personality identities. Education Strategies in Medical Sciences. 2019; 12(2): 73-79. [Persian]. [Link]

8. Hejazi E, Amani H, Yazdani MJ. Evaluation of psychometric properties of academic identity status measure in Iranian students. Journal of Psychological Methods and Models. 2011; 2(5): 1-15. [Persian]. [Link]

9. Butler-Barnes ST, Varner F, Williams A, Sellers R. Academic identity: a longitudinal investigation of African American adolescents' academic persistence. J Black Psychol. 2017; 43(7): 714-739. [Link]
10. Abbas NF, Al-Bahrani RH. The search for identity in online chat. International Journal of Humanities and Cultural Studies (IJHCS). 2016; 2(2): 8-15. [Link]

11. Thoonen EEJ, Sleegers PJC, Oort FJ, Peetsma TTD, Geijsel FP. How to improve teaching practices: the role of teacher motivation, organizational factors, and leadership practices. Educ Adm Q. 2011; 47(3): 496536. [Link]

12. Tabatabie N, Tabatabie SS, Kakai Y, Mohammadiaria A. The relationship between identity styles and responsibility with educational achievement in high school students in Tehran. Social Welfare Quarterly. 2012; 12(44): 23-42. [Persian]. [Link]

13. Hashemi T, Mostafavi F, Mashinchi Abbasi N, Badri R. Role of goal orientation, self-efficacy of selfregulation and personality in procrastination. Contemporary Psychology, Biannual Journal of the Iranian Psychological Association. 2012; 7(1): 73-84. [Persian]. [Link]

14. Jokaar B, Delaavarpoor M. The relationship between educational procrastination and goal orientation. New Thoughts on Education. 2008; 3(34): 61-80. [Persian]. [Link]

15. Nikpay I, Farahbakhsh S, Yousefvand L. The effect of self-regulated learning strategies (cognitive and Meta cognitive) on goal orientation in second grade girl high school students by 60 day follows up. New Educational Approaches. 2016; 11(2): 71-86. [Persian]. [Link]

16. Herndon JS, Bembenutty H. Self-regulation of learning and performance among students enrolled in a disciplinary alternative school. Pers Individ Dif. 2017; 104: 266-271. [Link]

17. Dehghani Nazhvani A, Zarepour M. Relationship between goal orientation and academic achievement in dental students of Shiraz University. Iranian Journal of Medical Education. 2016; 16: 210-218. [Persian]. [Link]

18. Veysi K, Talepasand S. Relationship between Achievement Goal Orientation, perceived classroom goal structures, cognitive and metacognitive strategies with math achievement. Cognitive Strategies in Learning. 2014; 2(2): 67-81. [Persian]. [Link]

19. Delavar A, Esmaeili N, Hasanvandi S, Hasanvand B. Relationship between types of goal orientation and self-regulated learning strategies with academic achievement. Educational Psychology. 2015; 11(36): 59-78. [Persian]. [Link]

20. Abroshan H. Prediction of self-regulation learning strategies and subjective-vitality based on goal orientation in high school students. Quarterly Journal 
of Education Studies. 2015; 1(2): 119-143. [Persian]. [Link]

21. Valipour M, Hosseinian S, Pourshahriari M. The effectiveness of cognitive therapy based on mindfulness on children's behavioral problems. Quarterly Journal of Child Mental Health. 2018; 4(4): 34-45. [Persian]. [Link]

22. Kristeller JL, Baer RA, Quillian-Wolever R. Mindfulness-based approaches to eating disorders. In:

Baer RA, editor. Mindfulness-based treatment approaches: Clinician's guide to evidence base and applications. San Diego, CA, US: Elsevier Academic Press; 2006, pp: 75-91. [Link]

23. Golpour Chamarkohi R, Mohammad Amini Z. The efficacy of mindfulness based stress reduction on mindfulness and assertiveness of students with test anxiety. Journal of School Psychology. 2012; 1(3): 82-100. [Persian]. [Link]

24. Was CA, Al-Harthy I, Stack-Oden M, Isaacson RM. Academic identity status and the relationship to achievement goal orientation. Electronic Journal of Research in Educational Psychology. 2009; 7(2): $627-$ 652. [Link]

25. Barezegar Barfooei K, Barzegar Barfooei M, Mollaee Bahrami Y. The role of goal orientation and metacognitive reading strategies in predicting academic motivation of male students of Yazd Farhangian University. Research in School and Virtual Learning. 2014; 2(5): 27-42. [Persian]. [Link] 26. Pintrich PR, De Groot EV. Motivational and selfregulated learning components of classroom academic performance. J Educ Psychol. 1990; 82(1): 33-40. [Link]

27. Arami Z, Manshaee GR, Abedi A, Sharifee T. The comparison of motivational beliefs, metacognitive skills and self-regulation learning between gifted \& ordinary students of the city of Isfahan. New Educational Approaches. 2016; 11(2): 59-70. [Persian]. [Link]

28. Nakhaei S, Amiri Majd M, Mohamadi Ariya AR, Shirazi M. Modeling the relationship between teachers' demographic characteristics and internal motivation of students by mediating cognitive and metacognitive strategies. Quarterly Journal of Child Mental Health. 2018; 4(4): 180-192. [Persian]. [Link]

29. Eisendrath SJ. Mindfulness-based cognitive therapy: innovative applications. Cham: Springer International Publishing; 2016, pp: 100-123. [Link]

30. Nechita F, Alexandru DO, Turcu-Ştiolică R, Nechita D. The influence of personality factors and stress on academic performance. Curr Health Sci J. 2015; 41(1): 47-61. [Link] 